Old Dominion University

ODU Digital Commons

OEAS Faculty Publications

Ocean, Earth \& Atmospheric Sciences

2008

\title{
Shallow Marine Carbonate Dissolution and Early Diagenesis-Implications from an Incubation Study
}

Xinping Hu

Old Dominion University

David J. Burdige

Old Dominion University, dburdige@odu.edu

Follow this and additional works at: https://digitalcommons.odu.edu/oeas_fac_pubs

Part of the Oceanography and Atmospheric Sciences and Meteorology Commons

\section{Repository Citation}

$\mathrm{Hu}$, Xinping and Burdige, David J., "Shallow Marine Carbonate Dissolution and Early Diagenesis-Implications from an Incubation Study" (2008). OEAS Faculty Publications. 147.

https://digitalcommons.odu.edu/oeas_fac_pubs/147

\section{Original Publication Citation}

Hu, X., \& Burdige, D. J. (2008). Shallow marine carbonate dissolution and early diagenesis-Implications from an incubation study. Journal of Marine Research, 66(4), 489-527. doi: 10.1357/002224008787157449 


\title{
Shallow marine carbonate dissolution and early diagenesis-Implications from an incubation study
}

\author{
by Xinping $\mathbf{H u}^{1,2}$ and David J. Burdige $\mathbf{e}^{1,3}$
}

\begin{abstract}
Surface carbonate sediments from sites on the Bahamas Bank with different seagrass densities were incubated across a range of $\mathrm{O}_{2}$ delivery rates, to study the controls on metabolic carbonate dissolution in these sediments. The results confirmed the $1: 1$ ratio between the rates of $\mathrm{O}_{2}$ consumption and carbonate dissolution, demonstrating that microbial respiration was the ratelimiting step in metabolic carbonate dissolution. Furthermore, the dissolution we observed was actually net dissolution resulting from coupled dissolution and reprecipitation. This carbonate reprecipitation occurs on the time scale of days, and significantly alters the pore water dissolved inorganic carbon (DIC) stable isotopic composition. The carbonate reprecipitation/dissolution ratios observed here were similar to those reported in the literature for other sediments. Dissolution/ reprecipitation appeared to involve preferential dissolution of high magnesium calcite and reprecipitation of a carbonate phase with a Mg content that was only slightly lower than that of the dissolving phase. This result agrees with conclusions in the literature that "Ostwald ripening" may be responsible for this reprecipitation.
\end{abstract}

\section{Introduction}

Shallow water carbonate sediments (carbonate banks/bays, and continental shelves) represent the second largest carbonate pool on Earth, despite the fact that they cover only $8 \%$ of the area of the modern ocean. Furthermore $\sim 40 \%$ of global oceanic carbonate production and accumulation occurs in these shallow water environments (Milliman, 1993). Sediments from carbonate banks (e.g., Florida-Bahamas Banks) are traditionally considered to be net carbonate depositional environments (e.g., Broecker and Takahashi, 1966) yet they also undergo significant dissolution in association with both aerobic and anaerobic microbial respiration processes (Morse et al., 1985; Walter and Burton, 1990; $\mathrm{Ku}$ et al., 1999). As a result, as much as $20-50 \%$ of the gross carbonate production may be dissolved before the sediments are permanently buried (Walter and Burton, 1990; Ku et al., 1999; Sanders, 2003). Carbonate dissolution also represents a negative feedback mechanism in the global carbon cycle that may potentially compensate for rising atmospheric

1. Department of Ocean, Earth and Atmospheric Sciences, Old Dominion University, Norfolk, Virginia, 23529, U.S.A.

2. Present address. Department of Marine Sciences, University of Georgia, Athens, Georgia, 30602, U.S.A.

3. Corresponding author.email: dburdige@odu.edu 
$\mathrm{CO}_{2}$ by supplying excess alkalinity to the water column (Archer et al., 1989, 1998; Caldeira and Rau, 2000)

In shallow water sediments, microbial respiration of organic matter is generally the driving force for the occurrence of carbonate dissolution, despite the fact that the overlying waters are supersaturated with respect to the common carbonate minerals found in these sediments (Morse et al., 1985; Walter and Burton, 1990; Green and Aller, 1998, 2001; Burdige and Zimmerman, 2002). In particular, aerobic respiration in the sediments generates metabolic $\mathrm{CO}_{2}$ and drives down the pore water saturation state with respect to the solubility of carbonate mineral phases such as calcite or aragonite; once the pore waters are sufficiently undersaturated, carbonate dissolution can occur. This process can be written in the following simplified fashion:

$$
\begin{gathered}
\mathrm{CH}_{2} \mathrm{O}+\mathrm{O}_{2} \rightarrow \mathrm{CO}_{2}+\mathrm{H}_{2} \mathrm{O} \\
\frac{\mathrm{CO}_{2}+\mathrm{CaCO}_{3}+\mathrm{H}_{2} \mathrm{O} \rightarrow \mathrm{Ca}^{2+}+2 \mathrm{HCO}_{3}^{-}}{\mathrm{CH}_{2} \mathrm{O}+\mathrm{O}_{2}+\mathrm{CaCO}_{3} \rightarrow \mathrm{Ca}^{2+}+2 \mathrm{HCO}_{3}^{-}}
\end{gathered}
$$

and an important aspect of this "metabolic" carbonate dissolution is that sediment $\mathrm{O}_{2}$ input is an important controlling factor in the occurrence of carbonate dissolution. In tropical and subtropical sediments, the presence of seagrasses growing in the sediments enhances benthic aerobic respiration, and hence carbonate dissolution, in two important ways: through subsurface pumping of $\mathrm{O}_{2}$ into the sediments from seagrass roots and rhizomes, and through increased input of sediment organic matter (Burdige and Zimmerman, 2002; Burdige et al., 2008).

In our previous work on Bahamas Bank sediments (Hu and Burdige, 2007), we were able to achieve a stable carbon isotope mass balance for the two sources of DIC being added to the pore waters by metabolic carbonate dissolution (Eq. 3) in intermediate density seagrass sediments and in bare oolitic sand sediments. However, in sediments with high seagrass densities we observed that the pore water DIC pool was enriched in ${ }^{13} \mathrm{C}$, and that its isotopic composition could not be explained by the 1:1 mixing of DIC derived from sediment carbonate dissolution and organic matter oxidation that is predicted by this equation. Similar observations have been reported in other shallow water estuarine and coastal sediments (McNichol et al., 1991; Eldridge and Morse, 2000; Walter et al., 2007), although an adequate explanation of these observations has not been presented. In contrast, we proposed a closed-system model to explain this pore water DIC ${ }^{13} \mathrm{C}$ enrichment based on the coupling between carbonate dissolution and reprecipitation (Hu and Burdige, 2007). Qualitatively, our model results agreed with the observations in these studies.

In this model, differences in the solubility of sedimentary carbonate phases (calcite, aragonite and high-Mg calcite or HMC) can lead to a situation in which the pore waters are undersaturated with respect to one or more metastable phase (e.g., HMC) yet are still supersaturated with respect to another more stable phase (e.g., calcite). Thus net sediment carbonate dissolution results from the balance between gross dissolution of the more 
soluble carbonate phase and reprecipitation of a more stable secondary phase. This secondary phase may indeed be a different carbonate mineral (e.g., Rude and Aller, 1991), although dissolution/reprecipitation may also occur through "Ostwald ripening," in which smaller crystals dissolve and reprecipitate on the surfaces of larger crystals, with no change in mineralogy. Here, the lower surface free energy of larger (versus smaller) crystals leads to the solubility differences that drive the dissolution/reprecipitation process (e.g., Hover $e t$ al., 2001). The HMC which reprecipitates in this manner may also have a very similar (although perhaps slightly lower) $\mathrm{Mg}$ content relative to the original material (Cole and Chakraborty, 2001; Hover et al., 2001).

In this paper, we describe a series of closed-system incubation experiments using surface sediments from sites on the Bahamas Bank that have different seagrass densities. In these experiments, sediments were incubated at a range of $\mathrm{O}_{2}$ input rates, and changes in pore water solute concentrations (e.g., alkalinity, DIC, calcium, sulfide) as well as the $\delta^{13} \mathrm{C}$ of the DIC were monitored over time. With the results of these studies we have quantitatively examined the dynamics of carbonate dissolution and reprecipitation in these sediments, along with the composition of the dissolving and reprecipitating carbonate phases. These data were also used to further verify the carbonate dissolution/reprecipitation model proposed in our previous work (Hu and Burdige, 2007).

\section{Materials and methods}

\section{a. Site descriptions}

The work described here was carried out during a 2003 field expedition to Lee Stocking Island (LSI), Exuma Cays, Bahamas, and on a cruise in 2004 aboard the R/V F. G. Walton Smith across the greater expanse of the Bahamas Bank (WS, see map in Fig. 1). Three sampling sites around LSI were studied-the Channel Marker (CM), Halfway (HW) and Ooids Shoals (OS) sites. On the WS cruise, studies were carried out at two sites-WS-3, located northwest of Andros Island and WS-13, located west of the Exuma Cays near Pipe Cay. Information about all of these sites can be found in Table 1 (also see Hu and Burdige, 2007 and Burdige et al., 2008).

The porosity of these sediments ranged from $45-65 \%$ (Table 1) with a grain size range of 200-800 $\mu \mathrm{m}$ (Burdige and Zimmerman, 2002; Hu, 2007). X-ray diffraction results (analytical procedures described in Section 2e) showed that these sediments were predominantly aragonite (70-90\%), with lesser amounts of high magnesium calcite, or HMC (10-30\%), and low magnesium calcite, or LMC $(<3 \%)$. The Mg content of the HMC was fairly uniform among these sites, ranging from 12.0-13.6 mol\% (Table 2).

\section{b. Sediment incubation studies}

Surface sediments $(0-2 \mathrm{~cm})$ from all sampling locations were collected by SCUBA divers with care taken to not mix these sediments with deeper sediments. Seagrass and large mollusk debris were removed immediately after sampling using a plastic sieve 


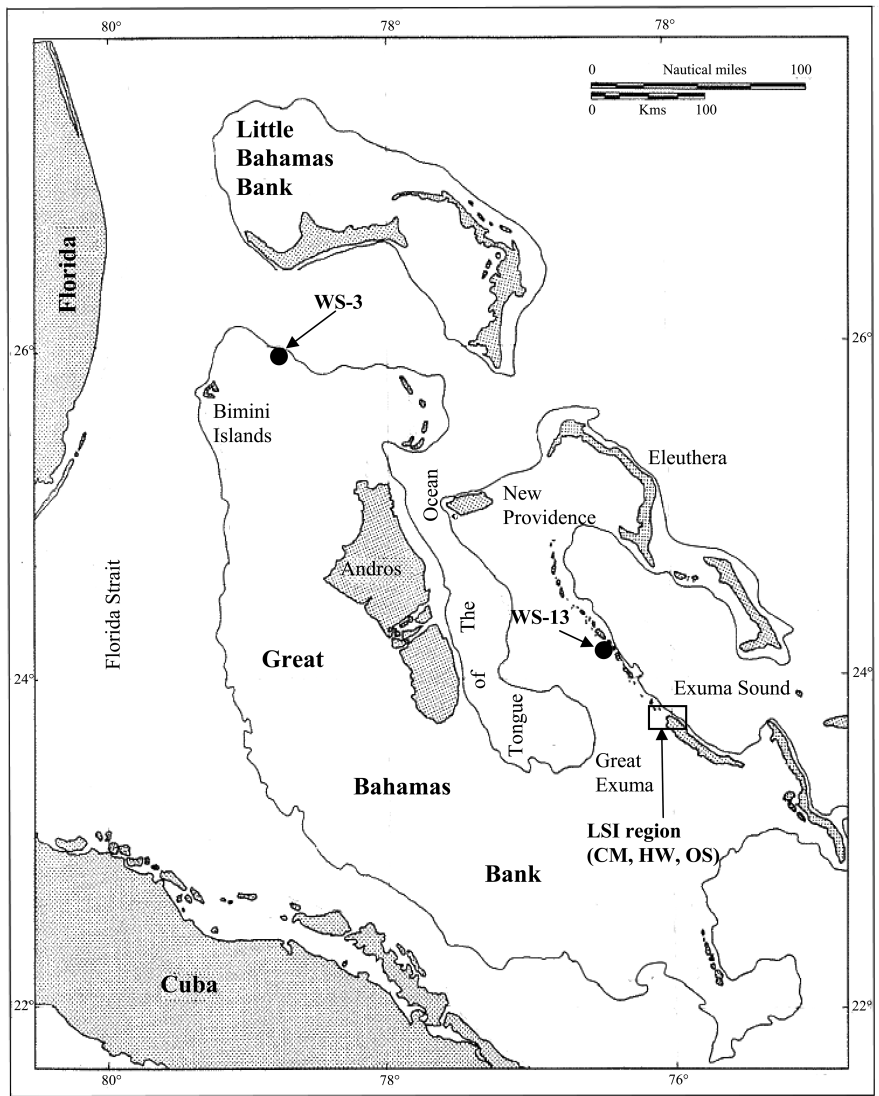

Figure 1. A map showing the sampling sites (modified from Bathurst, 1971). A detailed map of the LSI region showing the sites in this region (CM, HW, and OS) can be found in $\mathrm{Hu}$ and Burdige (2007).

$(\Phi=1 \mathrm{~mm})$, and the sediments were then washed with surface seawater collected at the sampling sites. During processing the sediments were stirred continuously to ensure that they were well oxygenated and homogenized.

The technique used in these incubation studies was modified from the approach described in Hulthe et al. (1998), and a schematic illustration of the experimental set-up is shown in Figure 2. As will be discussed below, the approach allowed us to incubate the sediments at different $\mathrm{O}_{2}$ delivery rates (Table 3). Either Teflon tubing (I.D. 0.38 mm, O.D. $0.8 \mathrm{~mm}$ ) or Cole-Parmer ${ }^{\circledR}$ C-Flex ${ }^{\mathrm{TM}}$ tubing (I.D. $0.79 \mathrm{~mm}$, O.D. $2.38 \mathrm{~mm}$ ) was passed through 10 Teflon-lined silicone septa and open-face caps to form a series of loops (exactly $20 \mathrm{~cm}$ in length), and the loops were inserted into $42 \mathrm{ml}$ glass vials. Surface seawater $(5.0 \mathrm{ml})$ was next added to each vial, and the vials were then filled with the well-mixed sediment. Finally, the vials were tightly screwed shut and the caps were secured with 
Table 1. Characterization of the sampling sites.

\begin{tabular}{lclcl} 
Station ID & $\begin{array}{c}\text { Water depth } \\
(\mathrm{m})\end{array}$ & \multicolumn{1}{c}{ Seagrass present } & Leaf area index $^{\mathrm{b}}$ & Porosity $(\varphi)$ \\
CM & 3.9 & Thalassia testudinum & $1.7 \pm 0.6$ & $0.65 \pm 0.03$ \\
HW & 3.0 & Thalassia testudinum & $0.6 \pm .2$ & $0.57 \pm 0.01$ \\
OS & 2.8 & None & 0 & $0.47 \pm 0.01$ \\
WS-3 & 10.5 & $\begin{array}{l}\text { Thalassia testudinum } \\
\text { Syringodium filiforme }\end{array}$ & 1.3 & $0.57 \pm 0.02$ \\
WS-13 & 4.2 & Thalassia testudinum & $0.54 \pm 0.04$ & $0.53 \pm 0.03$
\end{tabular}

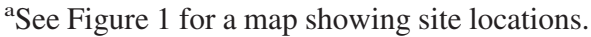

${ }^{\mathrm{b}}$ The unit of leaf area index (LAI) is $\mathrm{m}^{2}$-leaf $\mathrm{m}^{-2}$-sediments, and LAI values are from Burdige et al. (2008) and Bodensteiner (2006).

Parafilm ${ }^{\circledR}$ to prevent contamination from atmospheric $\mathrm{O}_{2}$. Aliquots of the sediment were sampled before, during the middle, and after the filling process, to determine the average porosity in the experimental sediments. The porosity data were used to calculate pore water volume in the incubation vials.

Blank experiments using vials filled with $\mathrm{N}_{2}$-purged seawater showed a net $\mathrm{O}_{2}$ gain of $\sim 1 \mu \mathrm{mol} \mathrm{kg} \mathrm{kg}^{-1} \mathrm{~d}^{-1}$. Therefore during a 4.5-5-day incubation there would have been a maximum $\mathrm{O}_{2}$ input into each vial of $\leq 5 \mu \mathrm{mol} \mathrm{kg}{ }^{-1}$, as compared with the $\mathrm{mmol} \mathrm{kg}^{-1}$ concentration changes of pore water solutes such as DIC, alkalinity or $\mathrm{Ca}^{2+}$. This small amount of oxygen "leakage" into the vials was thus negligible.

After the vials were filled with sediment and sealed, the gas diffusion tube for each series of incubation vials was connected to a compressed $\mathrm{N}_{2}, \mathrm{O}_{2}$ or air tank through a Norgren ${ }^{\circledR}$ gas pressure regulator. The tubing was flushed with gas before the end of the tube was heat-sealed. The gas regulator was then set at the desired pressure to establish the $\mathrm{O}_{2}$-delivery rate (see Section $2 \mathrm{c}$ ). The $\mathrm{O}_{2}$-delivery rates used here (Table 3 ) span the range of depth-integrated rates of seagrass $\mathrm{O}_{2}$ input to Bahamas Bank sediments (Bodensteiner, 2006; Burdige et al., 2008), when these integrated rates are converted to discrete rates (i.e.,

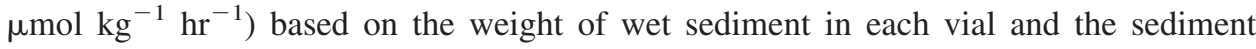
porosity. The vials were incubated in the dark at constant temperature in a flowing seawater bath (Table 3). All incubations were maintained at constant gas pressures except $13-\mathrm{H}$, in

Table 2. Mineralogy of the incubated surface sediments ${ }^{\mathrm{a}}$.

$\begin{array}{lcccc}\text { Station ID } & \text { Aragonite }(\mathrm{wt} \%) & \text { HMC }(\mathrm{wt} \%) & \text { LMC }(\mathrm{wt} \%) & \text { Mg in HMC (mole\%) } \\ \text { CM } & 64.3 \pm 1.4 & 32.4 \pm 1.9 & 3.3 \pm 2.0 & 12.2 \pm 0.1 \\ \text { HW } & 89.2 & 9.7 & 1.1 & 12.7 \\ \text { OS } & 87.3 & 11.2 & 1.4 & 13.6 \\ \text { WS-3 } & 81.4 \pm 0.4 & 17.2 \pm 0.4 & 1.3 \pm 0.0 & 12.0 \pm 0.1 \\ \text { WS-13 } & 91.2 \pm 0.1 & 7.8 \pm 0.1 & 1.0 \pm 0.2 & 12.3 \pm 0.1\end{array}$

${ }^{\mathrm{a}}$ Errors are standard deviations $(\mathrm{n}=3)$. 


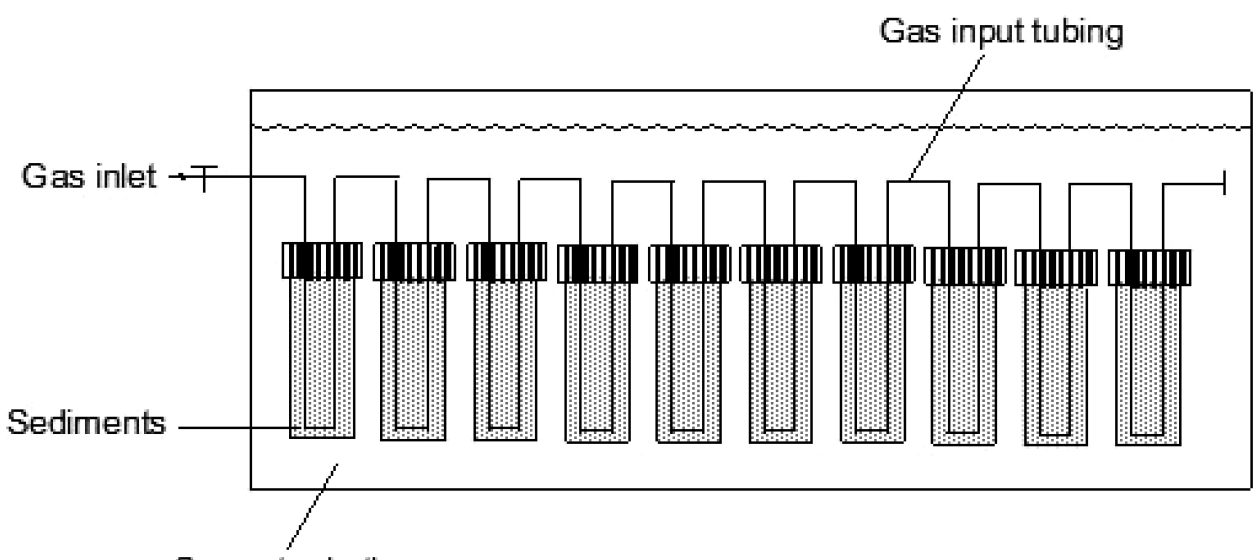

\section{Seawater bath}

Figure 2. A schematic illustration of the experimental set up.

which the $\mathrm{O}_{2}$ pressure was first set at 20 psi, and was then decreased to $10 \mathrm{psi}$ after $56 \mathrm{hrs}$ (to keep the pore water $\mathrm{O}_{2}$ concentration below saturation levels; see Fig. 3).

Immediately after an incubation was set up, the first time point was collected by cutting the tubing between the last two vials and heat-sealing the open end of the shortened piece of tubing attached to the last of the remaining vials. Subsequent time points were collected every $\sim 12$ hours for the next 4.5-5 days using the same procedure. Before pore water was collected from each vial, the vial was weighed to determine the total amount of wet sediment. Dry sediment and pore water weights in each vial were calculated using porosity data.

For each time point, the sediment in the vials was first re-homogenized by manually shaking the vials, and the $\mathrm{O}_{2}$ concentrations were determined by inserting an 18-gauge stainless steel sleeved fluorescence optical oxygen sensor (Ocean Optics ${ }^{\circledR}$ ) through the septa. The $\mathrm{O}_{2}$ sensor was calibrated using two $\mathrm{O}_{2}$ concentrations $-\mathrm{N}_{2}$ purged oxygen-free seawater and air-saturated seawater at a known salinity and temperature. The $\mathrm{O}_{2}$ concentration of the latter was calculated using the $\mathrm{O}_{2}$ solubility equation in Pilson (1998). Additional details about these $\mathrm{O}_{2}$ measurements can be found in $\mathrm{Hu}$ (2007).

The vials were next centrifuged at room temperature for 5 minutes in a clinical centrifuge at $3000 \mathrm{rpm}$ to separate the pore water from the sediments. This water was drawn into a clean polypropylene syringe and filtered through $0.45 \mu \mathrm{m}$ Gelman ${ }^{\circledR}$ Nylon Acrodisc filters. Samples for titration alkalinity $\left(\mathrm{Alk}_{\mathrm{T}}\right), \mathrm{pH}$ and total dissolved sulfide $\left(\Sigma \mathrm{H}_{2} \mathrm{~S}\right)$ were stored in air-tight vessels in a refrigerator (Hu and Burdige, 2007) and analyzed within 1-2 days of sampling. The remaining pore water was distributed into two crimp-sealed $2 \mathrm{ml}$ serum vials with no headspace (for DIC concentration and stable isotope analyses), and into a $2 \mathrm{ml}$ plastic snap-cap vial (for major ion analyses). These samples were stored in the dark in a refrigerator and analyzed within 3 months of collection. Finally the residual sediments were removed from the vial and stored frozen at $-20^{\circ} \mathrm{C}$. 
Table 3. Experimental settings for sediment incubations and general trends in the data.

\begin{tabular}{|c|c|c|c|c|c|}
\hline $\begin{array}{l}\text { Station } \\
\text { ID }\end{array}$ & $\begin{array}{l}\text { Tube } \\
\text { type }\end{array}$ & $\begin{array}{c}\text { Gas pressure } \\
\text { (psi)/gas } \\
\text { type }\end{array}$ & $\begin{array}{l}\mathrm{O}_{2} \text { input rates } \\
\left(\mu \mathrm{mol} \mathrm{h}{ }^{-1}\right)^{\mathrm{a}}\end{array}$ & $\begin{array}{l}\text { Incubation } \\
\text { designation }^{\mathrm{b}}\end{array}$ & $\begin{array}{c}\text { Temperature } \\
\left({ }^{\circ} \mathrm{C}\right)\end{array}$ \\
\hline \multirow[t]{5}{*}{$\mathrm{CM}$} & \multirow[t]{5}{*}{ Teflon } & $20 / \mathrm{N}_{2}$ & 0 & CM-G & \multirow[t]{5}{*}{$28 \pm 1$} \\
\hline & & 6/air & 0.07 & CM-P & \\
\hline & & 12/air & 0.15 & CM-R & \\
\hline & & 20/air & 0.24 & CM-B & \\
\hline & & $20 / \mathrm{O}_{2}$ & 0.58 & CM-W & \\
\hline \multirow[t]{4}{*}{ HW } & \multirow[t]{4}{*}{ Teflon } & $20 / \mathrm{N}_{2}$ & 0 & HW-G & \multirow[t]{4}{*}{$28 \pm 1$} \\
\hline & & 2.5/air & 0.03 & HW-P & \\
\hline & & 5/air & 0.06 & HW-R & \\
\hline & & 10/air & 0.12 & HW-B & \\
\hline \multirow[t]{4}{*}{ OS } & \multirow[t]{4}{*}{ Teflon } & $20 / \mathrm{N}_{2}$ & 0 & OS-G & \multirow[t]{4}{*}{$28 \pm 1$} \\
\hline & & 5/air & 0.06 & OS-P & \\
\hline & & 10/air & 0.12 & OS-R & \\
\hline & & 20/air & 0.24 & OS-B & \\
\hline \multirow[t]{3}{*}{ WS-3 } & Teflon & $20 / \mathrm{N}_{2}$ & 0 & $3-\mathrm{N}$ & \multirow[t]{3}{*}{$22 \pm 2$} \\
\hline & C-Flex & $15 / \mathrm{O}_{2}$ & 4.29 & $3-\mathrm{L}$ & \\
\hline & C-Flex & $25 / \mathrm{O}_{2}$ & 7.15 & $3-\mathrm{H}$ & \\
\hline \multirow[t]{3}{*}{ WS-13 } & Teflon & $20 / \mathrm{N}_{2}$ & 0 & $13-\mathrm{N}$ & \multirow[t]{3}{*}{$23 \pm 1$} \\
\hline & Teflon & $30 / \mathrm{O}_{2}$ & 0.88 & $13-\mathrm{L}$ & \\
\hline & C-Flex ${ }^{c}$ & $20 / 10 / \mathrm{O}_{2}$ & $5.72 / 2.86$ & $13-\mathrm{H}$ & \\
\hline
\end{tabular}

${ }^{\mathrm{a}} \mathrm{O}_{2}$ input rates were calculated as discussed in Section $2 \mathrm{c}$.

${ }^{\mathrm{b}}$ Incubation vials were color-coded in the LSI experiments, G (green), P (pink), R (red), B (blue), and $\mathrm{W}$ (white), in which $\mathrm{W}$ was used for $\mathrm{O}_{2}$ treated $\mathrm{CM}$ incubation only. For the WS incubations, treatments were coded as $\mathrm{N}$ (nitrogen), $\mathrm{L}\left(\right.$ low $\mathrm{O}_{2}$ ), and $\mathrm{H}$ (high $\mathrm{O}_{2}$ ).

${ }^{\mathrm{c}}$ In the 13-H incubation, the $\mathrm{O}_{2}$ gas pressure was first set at $20 \mathrm{psi}_{2}$ for the initial 56 hours, and it was then decreased to $10 \mathrm{psi}$ for the rest of incubation to keep the pore water $\mathrm{O}_{2}$ concentration below saturation levels (see Fig. 3).

\section{c. Calibration of the $\mathrm{O}_{2}$ diffusion tubes}

The oxygen delivery rate as a function of $\mathrm{O}_{2}$ partial pressure was determined in the lab for each type of diffusion tubing, using the same basic experimental set-up that was used in the field studies. Here however, vials that contained a $20 \mathrm{~cm}$ tubing loop were filled with $\mathrm{N}_{2}$-purged seawater rather than sediment. After the tubing was flushed, heat-sealed and the gas pressure set on the regulator, the $\mathrm{O}_{2}$ concentration in a given vial was monitored over time with the optical oxygen sensor described above (Fig. 4). The results of these time courses (e.g., the slope of the line in the inserts to this figure) were plotted as a function of tubing gas pressure and used to construct calibration curves $\left(\mathrm{O}_{2}\right.$ delivery rate vs. regulator pressure) for both pure $\mathrm{O}_{2}$ and air as the delivery gas. For each type of tubing and delivery gas, oxygen concentrations increased linearly with time (at a given gas pressure); oxygen delivery rate was also a linear function of gas pressure (Fig. 4). 

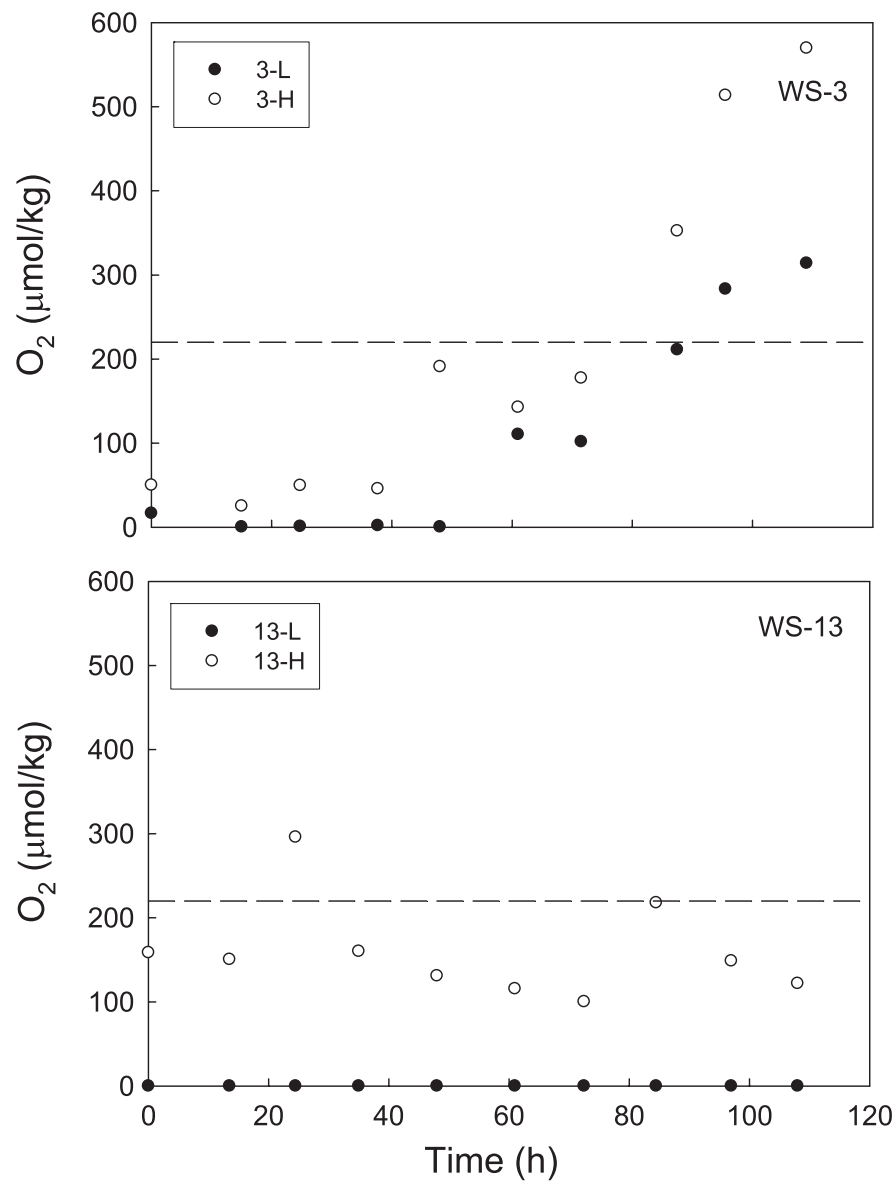

Figure 3. Changes in pore water oxygen concentration in the WS-3 and WS-13 incubations. The dashed lines represent $\mathrm{O}_{2}$ saturation at the experimental conditions $\left(220 \mu \mathrm{mol} \mathrm{kg}^{-1}\right)$.

\section{d. Chemical and isotopic analyses}

Total alkalinity $\left(\mathrm{Alk}_{\mathrm{T}}\right)$ was determined on $2-3 \mathrm{ml}$ samples by Gran Titration using a Metrohm automatic titrator combined with a Cole-Parmer $\mathrm{pH}$ electrode, calibrated using pH 4.00, 7.00 and 10.00 NIST-traceable buffers (Grasshoff et al., 1999). The titrant used was $0.02 \mathrm{~N} \mathrm{HCl}$ (Fisher certified) and Scripps Reference Seawater (Dickson et al., 2003) was also used as an external reference standard. Total dissolved sulfide $\left(\sum \mathrm{H}_{2} \mathrm{~S}\right)$ was determined using the spectrophotometric method described in Cline (1969). A UIC Coulometer was used to determine dissolved inorganic carbon (DIC) for all samples (Dickson et al., 2007). Dissolved calcium was determined on $0.1 \mathrm{ml}$ pore water samples by automated EGTA titration with end point detection using a Thermo Orion $\mathrm{Ca}^{2+}$ ionselective electrode (Kanamori and Ikegami, 1980). Chlorinity (chloride concentration) was 

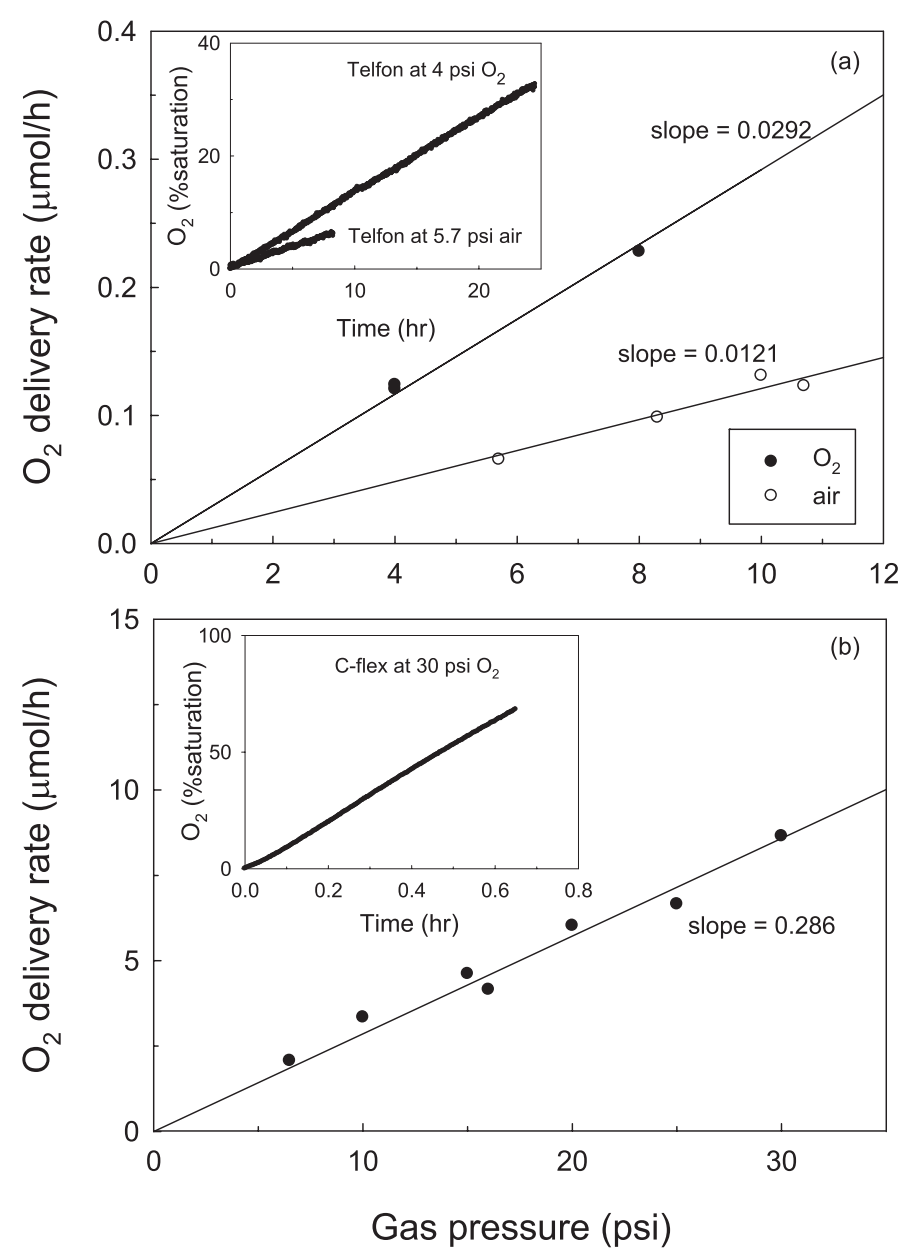

Figure 4. Calibration curves for $\mathrm{O}_{2}$ delivery from Teflon tubing (a), and C-flex tubing (b). The inserts are examples of individual $\mathrm{O}_{2}$ concentration changes as a function of time for different gas and tubing types (at a fixed gas pressure). The slopes of these lines were used to generate the calibration curves shown here.

also determined by automated silver nitrate titration with end-point detection by a Brinkman Ag Titrode ${ }^{\mathrm{TM}}$ (Metrohm Ti Application Note No. T-1). Both titrants (EGTA and $\mathrm{AgNO}_{3}$ ) were standardized using IAPSO standard seawater (Grasshoff et al., 1999). Samples from the WS-3 and WS-13 incubations were analyzed for $\delta^{13} \mathrm{C}$ of the pore water DIC on a PDZ Europa 20-20 isotopic ratio mass spectrometer (IRMS), using a modification of the procedure of Salata et al. (2000) as described in Hu and Burdige (2007).

Oven dried $\left(60^{\circ} \mathrm{C}\right)$ sediment samples were analyzed for $\delta^{13} \mathrm{C}$ of the sediment carbonate by acidification in a "Kiel" device using pure phosphoric acid at $90^{\circ} \mathrm{C}$, with the resultant $\mathrm{CO}_{2}$ gas then introduced into a PDZ Europa ${ }^{\circledR}$ GEO 20-20 IRMS. Seagrass samples were 
also analyzed for the $\delta^{13} \mathrm{C}$ of the organic carbon with a Carlo Erba NA1500 elemental analyzer (EA) interfaced with the IRMS. Before analysis, samples were acid-cleaned and oven-dried at $60^{\circ} \mathrm{C}$ followed by grinding to fine powder with a mortar and pestle (Grice $e t$ $a l ., 1996)$. All isotopic values are reported relative to the PDB standard. The seagrass $\mathrm{C} / \mathrm{N}$ ratio was calculated based on EA peak intensities calibrated with an asparagine standard (Joy Davis, pers. comm.).

Uncertainties of these analyses were: alkalinity $( \pm 2 \%)$, DIC $( \pm 2 \%), \mathrm{Ca}^{2+}( \pm 1 \%)$, chlorinity $( \pm 0.2 \%), \delta^{13} \mathrm{C}( \pm 0.2 \%), \Sigma \mathrm{H}_{2} \mathrm{~S}( \pm 2 \%), \mathrm{O}_{2}( \pm 3 \%)$.

\section{e. Mineralogy}

Sediment mineralogy was determined by X-ray diffraction (XRD) using a Philips PW $1729 \mathrm{X}$-ray generator with $\mathrm{Cu}-\mathrm{K} \alpha$ nickel filtered radiation at $40 \mathrm{kV}$ and $30 \mathrm{~mA}$. Scans were run from $25^{\circ}$ to $32^{\circ} 2 \theta$ with a scanning step of $0.02^{\circ} 2 \theta$ and a measuring time of $2 \mathrm{~s}$ per step. Crushed oyster shells (Crassostrea, calcite) and coral (Porites, aragonite) were used as carbonate standards (e.g., Milliman, 1974). Additional details about these analytical procedures can be found elsewhere (Morse et al., 1985; Hu, 2007; Hu and Burdige, 2007). The uncertainty in our results (i.e., \%HMC, \%LMC, and \%aragonite) was $<1.5 \%(1 \sigma$, $\mathrm{n}=3$ ), although the accuracy of this XRD method is generally considered to be $\pm 3-5 \%$ (Morse et al., 1985; Andrews, 1991; Milliman et al., 1993).

The Mg content of the HMC was also determined by XRD (Goldsmith et al., 1961) and the uncertainty of this measurement was $<0.5 \%$. Past studies of natural carbonates have shown that the Mg content of HMC determined by XRD agrees well with bulk chemical analyses of HMC (Walter and Morse, 1984).

\section{Results}

\section{a. Pore water chemistry}

$i$. Overview of the results. Closed-system incubations of carbonate sediments under different $\mathrm{O}_{2}$ input rates essentially exhibit three types of behaviors: (1) anoxic remineralization, when the $\mathrm{O}_{2}$ input rate is zero, (2) the apparent co-occurrence of oxic and anoxic remineralization, when $\mathrm{O}_{2}$ input is low compared to $\mathrm{O}_{2}$ consumption potential, and (3) oxic remineralization, when $\mathrm{O}_{2}$ input is greater than or equal to $\mathrm{O}_{2}$ consumption.

When the $\mathrm{O}_{2}$ input rate is zero (case 1 above, i.e., the diffusion tube was pressurized with $\mathrm{N}_{2}$ gas), the incubated sediments become $\mathrm{O}_{2}$ free shortly after the incubations were set up. Although the initial sediments were well mixed and oxygenated during experimental setup, by the time the first time points were collected $(<1 \mathrm{hr})$, sediment $\mathrm{O}_{2}$ levels were zero except in some of the incubations with high $\mathrm{O}_{2}$ delivery rates. Sulfate then becomes the next major electron acceptor in organic matter remineralization, because nitrate, $\mathrm{Mn}$ oxides, and Fe oxides are all found at very low levels in these carbonate sediments (Morse et al., 1985; Burdige, 2006).

In these anoxic incubations, pore water alkalinity and DIC levels increase as a result of sulfate reduction. Pore water saturation states with respect to carbonate minerals such as 
calcite or aragonite may initially decrease when there are low amounts of sulfate reduction ( $\sim 0.7 \mathrm{mmol} \mathrm{kg}{ }^{-1}$ loss of sulfate) and lead to slight amounts of carbonate dissolution. However, as sulfate reduction progresses, the buildup of pore water alkalinity generally leads to authigenic carbonate precipitation, as reflected by the depletion of $\mathrm{Ca}^{2+}$ over time (Walter and Burton, 1990; Stoessell, 1992; Boudreau and Canfield, 1993).

When $\mathrm{O}_{2}$ consumption is rapid as compared to $\mathrm{O}_{2}$ input from the diffusion tube (case 2), pore waters of the incubated sediments will have no dissolved $\mathrm{O}_{2}$, and aerobic respiration and sulfate reduction can co-occur in microenvironments within the vials (i.e., aerobic respiration in regions close to the diffusion tube and sulfate reduction farther away). Some of the $\mathrm{O}_{2}$ consumption is also likely involved in re-oxidation of sulfide to sulfate. The combination of sulfate reduction and sulfide oxidation is functionally equivalent to aerobic respiration (Eq. 1) according to:

$$
\begin{gathered}
2 \mathrm{CH}_{2} \mathrm{O}+\mathrm{SO}_{4}^{2-} \rightarrow 2 \mathrm{HCO}_{3}^{-}+\mathrm{H}_{2} \mathrm{~S} \\
\frac{2 \mathrm{O}_{2}+\mathrm{H}_{2} \mathrm{~S} \rightarrow 2 \mathrm{H}^{+}+\mathrm{SO}_{4}^{2-}}{\mathrm{CH}_{2} \mathrm{O}+\mathrm{O}_{2} \rightarrow \mathrm{CO}_{2}+\mathrm{H}_{2} \mathrm{O} .}
\end{gathered}
$$

This implies that in these experiments $\mathrm{O}_{2}$ input can be thought of as solely driving aerobic respiration, which can then presumably mediate carbonate dissolution (rxn. 3). Due to the co-occurrence here of net sulfate reduction and aerobic respiration, pore water alkalinity and DIC come from two sources, i.e., metabolic carbonate dissolution and sulfate reduction.

When the $\mathrm{O}_{2}$ input rate is greater than or equal to the rate of sediment $\mathrm{O}_{2}$ consumption (case 3), dissolved oxygen will be observed in the pore waters. Aerobic oxidation of organic matter and metabolic carbonate dissolution are therefore the dominant reactions which occur. Alkalinity, DIC, and $\mathrm{Ca}^{2+}$ concentrations are expected to increase, with the alkalinity increase essentially coming solely from carbonate dissolution.

ii. $\mathrm{O}_{2}$ and sulfide concentration changes. All sediments used in these studies were initially well mixed and oxygenated, and in all studies except those using $\mathrm{N}_{2}$ as the diffusion gas, oxygen was continuously added to the sediments during the course of the incubations. However, in many of the studies $\mathrm{O}_{2}$ could not be detected in the sediments once the incubations were initiated (cases 1 and 2 above). These included all of the CM, HW, OS incubations, and the 3-N, 13-N and 13-L incubations (see Table 3). Dissolved $\mathrm{O}_{2}$ was detected in the incubations that used C-Flex, versus Teflon, tubing (3-L, 3-H, and 13-H; see Fig. 3), which suggests that here aerobic respiration was the sole carbon oxidation process (i.e., case 3 above).

Total dissolved sulfide $\left(\mathrm{SH}_{2} \mathrm{~S}\right)$ was observed in some CM-incubation pore waters at the first time point, and all incubated $\mathrm{CM}$ sediments with or without $\mathrm{O}_{2}$ input produced significant amounts of $\Sigma \mathrm{H}_{2} \mathrm{~S}\left(0.9-2.1 \mathrm{mmol} \mathrm{kg}^{-1}\right.$ at the end of each incubation; 

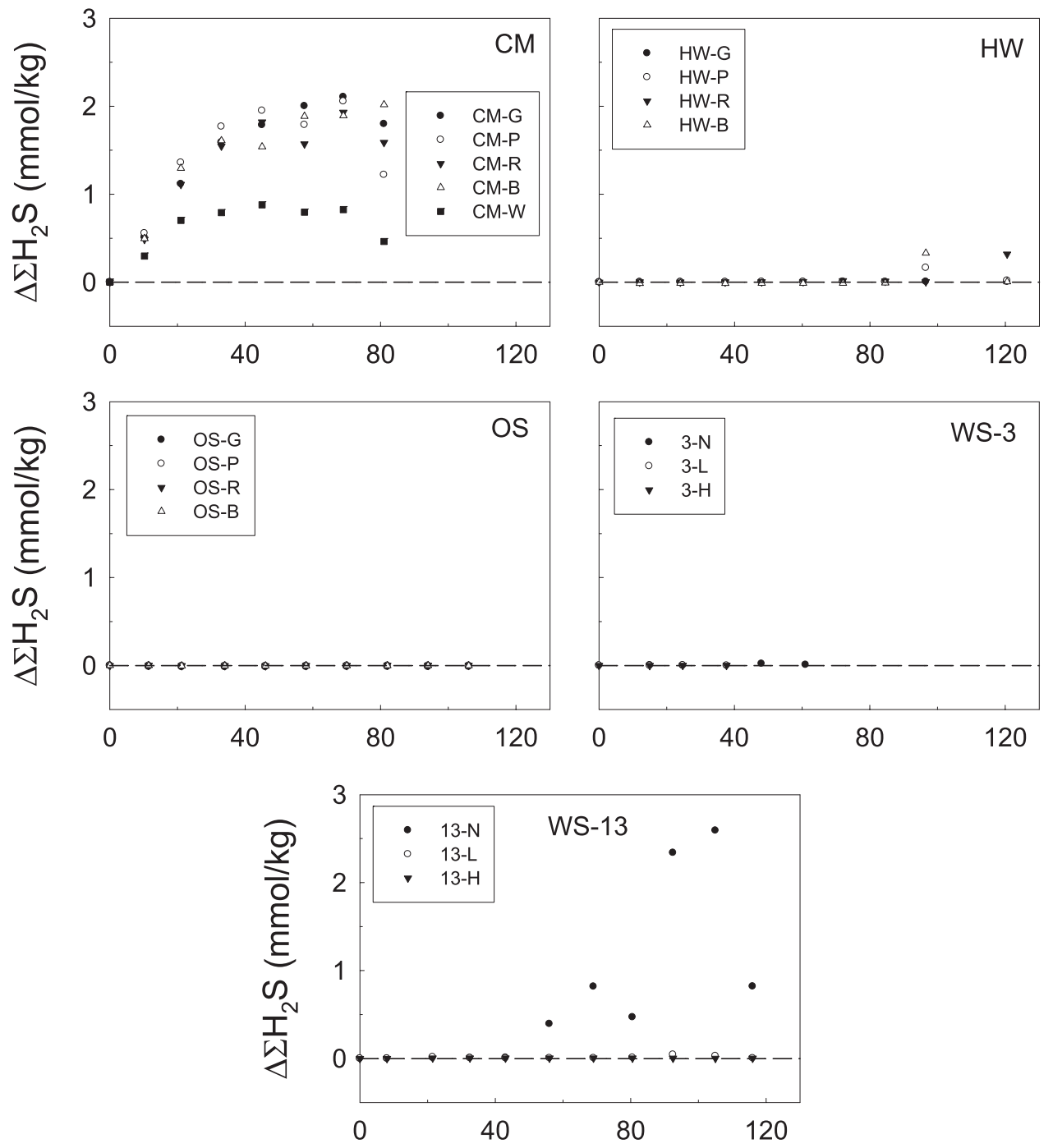

Time (h)

Figure 5. Concentrations of total dissolved sulfide $\left(\Sigma \mathrm{H}_{2} \mathrm{~S}\right)$ versus time in the pore waters of all experimental incubations. Concentrations are expressed relative to starting pore water concentrations (i.e., $\Delta \Sigma \mathrm{H}_{2} \mathrm{~S}$ ).

Fig. 5). Low levels of sulfide were detected in the HW incubations $\left(\sim 0.01 \mathrm{mmol} \mathrm{kg}^{-1}\right)$, while no sulfide was detected in the OS incubations. A slight increase in sulfide was observed in the 3-N incubation and no sulfide was present in either the 3-L or 3-H incubation, consistent with the occurrence here of dissolved $\mathrm{O}_{2}$ in the pore waters. In 
the WS-13 incubations, significant sulfide production was observed in the $13-\mathrm{N}$ incubation, and the 13-H incubation showed no sulfide, again consistent with the occurrence here of dissolved $\mathrm{O}_{2}$ in the pore waters. The 13-L incubation showed low level of sulfide $\left(<0.05 \mathrm{mmol} \mathrm{kg}^{-1}\right)$, although when compared to the magnitude of DIC production in this incubation (up to $4 \mathrm{mmol} \mathrm{kg}^{-1}$ ) it appeared that net sulfate reduction was negligible. As a result, in the remaining discussion, we will also treat $13-\mathrm{L}$ as an aerobic (case 3 ) incubation.

iii. Titration alkalinity, total DIC, and calcium concentration changes. Changes in $\mathrm{Alk}_{\mathrm{T}}$, DIC, and $\left[\mathrm{Ca}^{2+}\right]$ during each set of incubations are shown in Figures 6-8. These concentrations are expressed relative to starting concentrations, hence a $\Delta$ concentration $(\Delta C)$ notation is used in the tables and figures. Since these incubations were carried out under closed-system conditions, chlorinity (salinity) did not change significantly with time (Table 4).

In such closed-system incubations, nonlinear concentration changes can occur (e.g., Rude and Aller, 1991); and in many of our incubations, pore water solute concentrations initially increased and then leveled off with time. To describe the reaction rates and stoichiometry in these studies, linear regressions were calculated between $\Delta \mathrm{C}$ and time for the linear portion of each time course. The range of data points used in each fitting was based on the maximum range over which there was a statistically significant linear slope and a best-fit y-intercept equal to $0( \pm 1 \sigma)$ (Table 5$)$.

All incubations showed a slight decrease in $\mathrm{pH}(\mathrm{Hu}, 2007)$. This observation agrees with the results of a closed-system organic carbon remineralization model for carbonate sediments (Boudreau and Canfield, 1993), in which both aerobic respiration (when $\mathrm{O}_{2}$ is present) and sulfate reduction (when $\mathrm{O}_{2}$ is depleted) lead to a decrease in pore water $\mathrm{pH}$ as the reactions progress.

According to rxns. (3) and (4), pore water alkalinity and DIC production rates should equal one other, regardless of the organic matter remineralization pathway (i.e., aerobic vs. sulfate-reducing), if carbonate dissolution accompanies aerobic respiration but not sulfate reduction. Except for four of the five CM incubations, this was indeed the case (Fig. 9; Table 5). We believe that the DIC production rates for these four CM incubations are low since other solute production rates $\left(\mathrm{A}_{\mathrm{T}}\right.$, sulfide and $\left.\mathrm{Ca}^{2+}\right)$ appear to be consistent with each other, whereas the DIC production rates are not. These measured alkalinities are also consistent with calculated values of alkalinity based on the summation of the concentrations of the individual chemical species that contribute to the measured alkalinity (i.e., carbonate, bicarbonate, bisulfide, etc.; $\mathrm{Hu}, 2007)$. The reason for low DIC production rates in these four $\mathrm{CM}$ incubations is unclear at the present time, although one possible explanation involves sulfide interference with the coulometric DIC analyses (Dickson et al., 2007). The fact that we may see evidence for this possible interference in these CM incubations alone is perhaps not surprising, since these incubations showed sulfide concentrations (and rates of sulfide production) that were significantly greater than those 

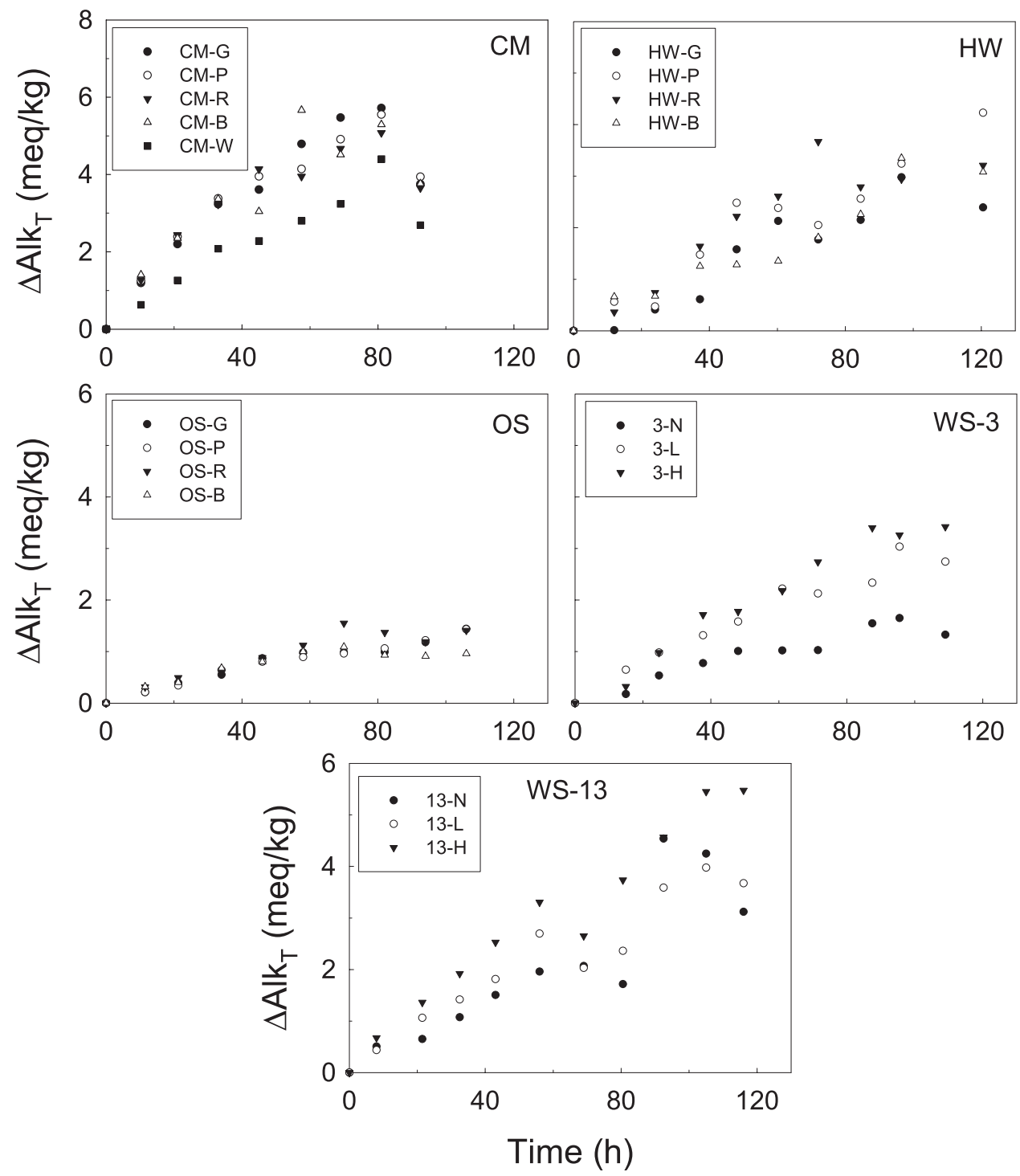

Figure 6. Concentrations of total titration alkalinity versus time in the pore waters of all experimental incubations. Concentrations are expressed relative to starting pore water concentrations (i.e., $\left.\Delta \mathrm{Alk}_{\mathrm{T}}\right)$.

seen in the other incubations (see Fig. 5 and Section 3a.ii), including the CM-W incubation for which there was good agreement between $A_{T}$ and DIC production rates (Fig. 9).

iv. Pore water saturation state. In these experiments it appears that the pore waters were either supersaturated or close to saturation with respect to aragonite (Fig. 10). 

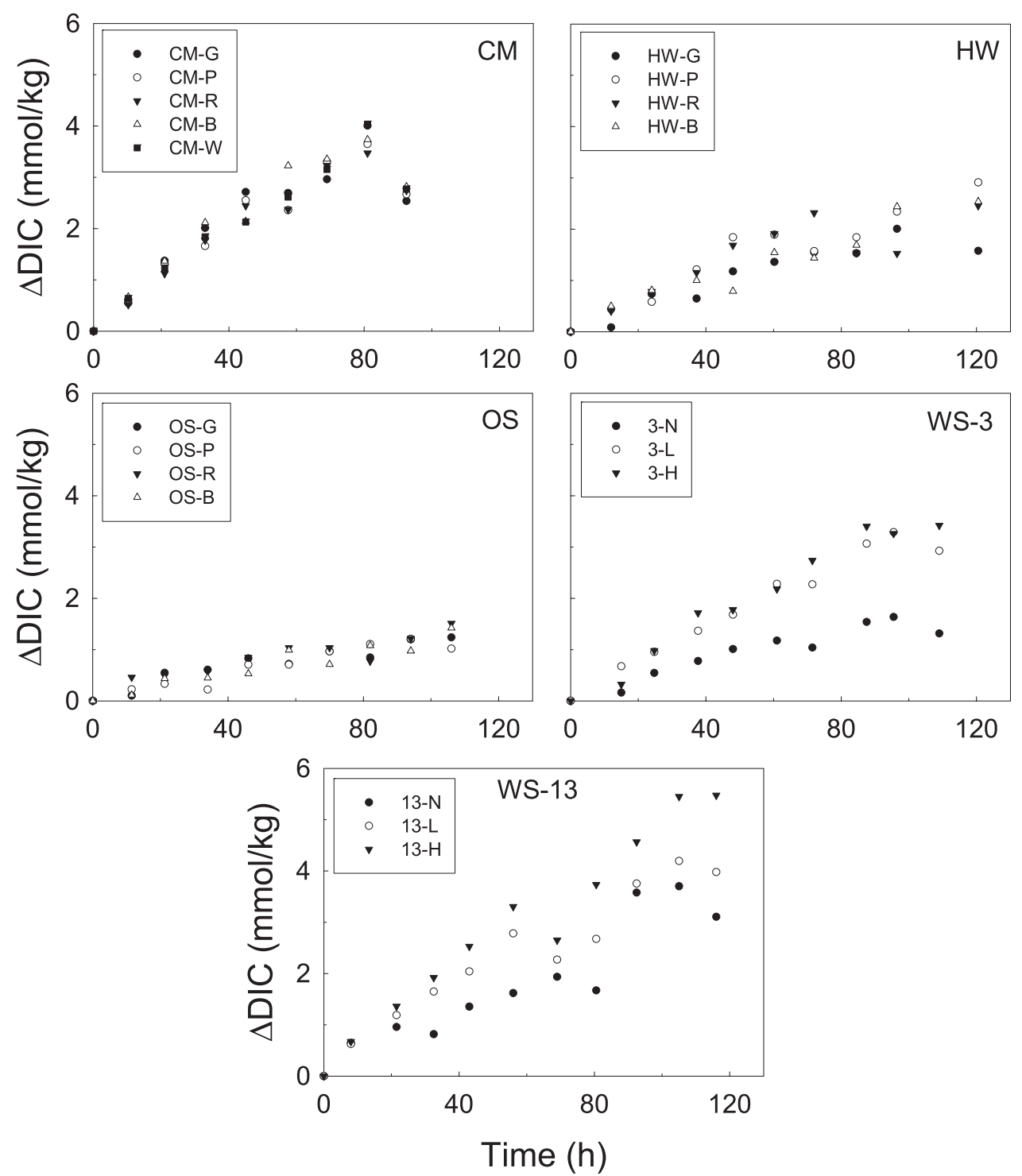

Figure 7. Concentrations of total dissolved inorganic carbon versus time in the pore waters of all experimental incubations. Concentrations are expressed relative to starting pore water concentrations (i.e., $\Delta \mathrm{DIC}$ ).

\section{b. Stable carbon isotopes}

Isotopic values of both carbonate sediments and seagrass are listed in Table 6. Pore water DIC $\delta^{13} \mathrm{C}$ changes with time in WS-3 and WS-13 experiments are shown in Figure 11. DIC $\delta^{13} \mathrm{C}$ values in WS-3 pore waters first showed a drop from the initial value 

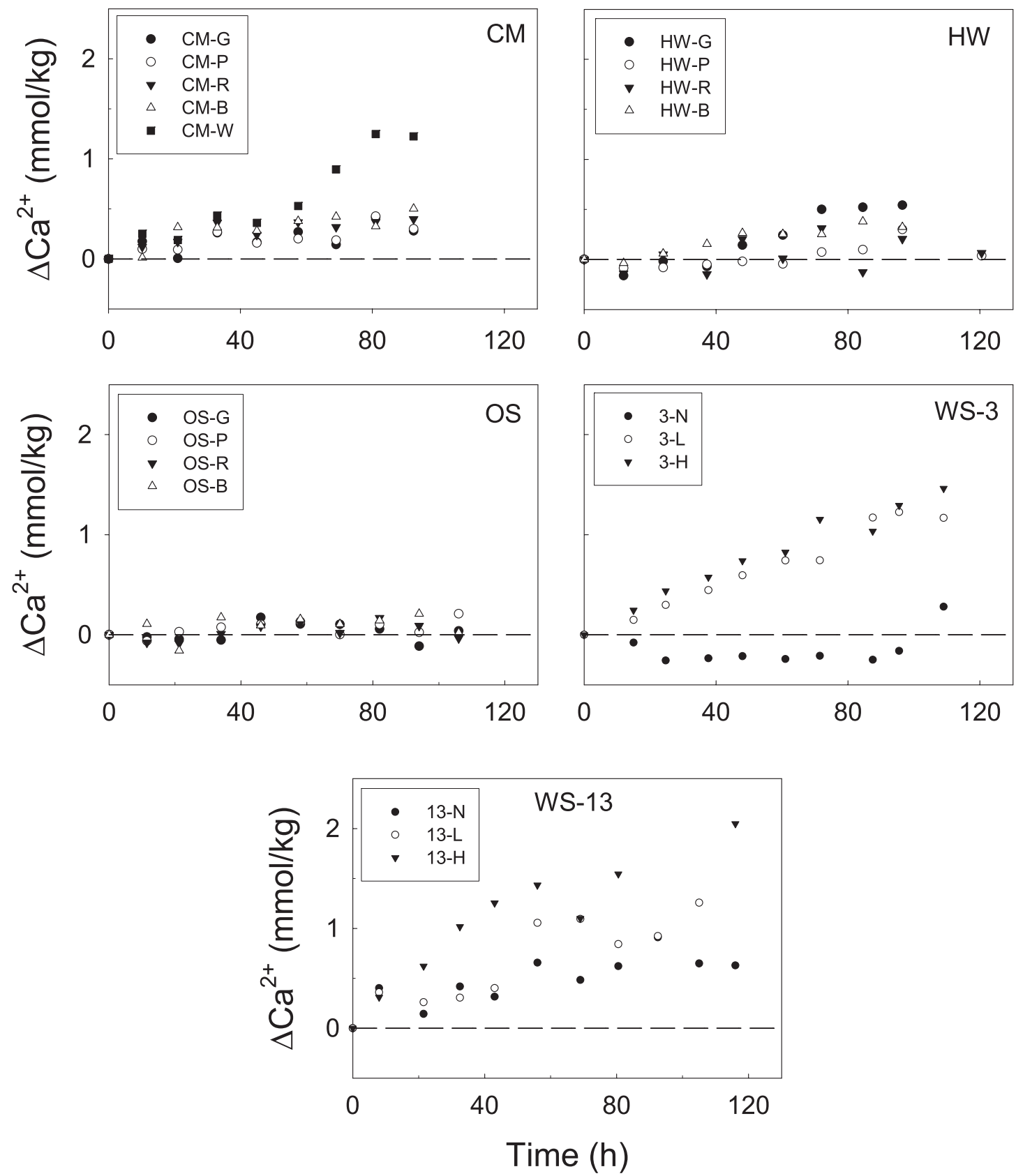

Figure 8. Concentrations of dissolved calcium versus time in the pore waters of all experimental incubations. Concentrations are expressed relative to starting pore water concentrations (i.e., $\left.\Delta \mathrm{Ca}^{2+}\right)$. 
Table 4. Pore water salinities in the incubations ${ }^{\mathrm{a}}$.

CM HW OS WS-3 WS-13

$\begin{array}{lccccc}{\left[\mathrm{Cl}^{-}\right](\mathrm{mmol} \mathrm{kg}} & -1 \\ \text { Salinity }^{\mathrm{b}} & 584.6 \pm 2.6 & 592.6 \pm 3.9 & 589.0 \pm 3.0 & 571.0 \pm 1.5 & 581.1 \pm 3.9 \\ \mathrm{CV}(\%) & 37.5 \pm 0.2 & 38.0 \pm 0.3 & 37.8 \pm 0.2 & 36.6 \pm 0.1 & 37.8 \pm 0.2 \\ \mathrm{~N} & 0.4 & 0.7 & 0.5 & 0.3 & 0.7 \\ & 45 & 40 & 40 & 20 & 20\end{array}$

${ }^{\text {a }}$ For each site these are averages of the analyses of all vials from all incubations. Uncertainties are standard deviations of the analysis.

${ }^{\mathrm{b}}$ Based on the chloride concentration and a chloride:salinity ratio in seawater of 15.80 (Pilson, 1998).

and then gradually increased as DIC concentration increased. DIC $\delta^{13} \mathrm{C}$ values in WS-13 pore waters $(0-56 \mathrm{hrs})$ increased slightly in both the $13-\mathrm{L}$ and $13-\mathrm{H}$ incubations, with no obvious trend observed in the $13-\mathrm{N}$ incubation.

Table 5. Reaction rates in the sediment incubations ${ }^{\mathrm{a}}$.

Time

range

Experiment

(h)

Time

$\mathrm{CM}$

CM-G

0-33

CM-P

$0-33$

CM-R

0-21

CM-B

$0-33$

CM-W

0-33

$\underset{\left(\mu e q \mathrm{~kg}^{-1} \mathrm{~h}^{-1}\right)}{\mathrm{r}_{\text {alk }}}$

$\left(\mu \mathrm{mol}^{-1} \mathrm{~kg}^{\mathrm{r}_{\mathrm{DIC}}} \mathrm{h}^{-1}\right)$

Time

range

(h) $\left(\mu \mathrm{mol} \mathrm{kg} \mathrm{kg}^{-1} \mathrm{~h}^{-1}\right)$

HW

$\begin{array}{lllllll}\text { HW-G } & 0-128.5 & 26 \pm 4 & 0-104.5 & 20 \pm 2 & 0-60.3 & {[0 \pm 1]} \\ \text { HW-P } & 0-80 & 35 \pm 7 & 0-68.3 & 33 \pm 3 & 0-84.5 & 2 \pm 1 \\ \text { HW-R } & 0-92.5 & 42 \pm 6 & 0-80 & 31 \pm 1 & 0-72 & 4 \pm 2 \\ \text { HW-B } & 0-104.5 & 29 \pm 3 & 0-45.3 & 26 \pm 4 & 0-72 & 5 \pm 1\end{array}$

OS

$\begin{array}{llllllc}\text { OS-G } & 0-58 & 17 \pm 1 & 0-46 & 19 \pm 3 & 0-70 & {[2 \pm 1]} \\ \text { OS-P } & 0-58 & 16 \pm 1 & 0-94 & 13 \pm 1 & 0-58 & 3 \pm 1 \\ \text { OS-R } & 0-70 & 20 \pm 1 & 0-58 & 16 \pm 2 & 0-58 & {[3 \pm 1]} \\ \text { OS-W } & 0-46 & 17 \pm 2 & 0-58 & 15 \pm 3 & 0-58 & {[3 \pm 2]}\end{array}$

WS-3

$\begin{array}{ccccccc}3-\mathrm{N} & 0-109 & 14 \pm 2 & 0-109 & 14 \pm 2 & 0-109 & {[-2 \pm 1]} \\ 3-\mathrm{L} & 0-109 & 28 \pm 2 & 0-109 & 33 \pm 1 & 0-109 & 12 \pm 0 \\ \text { 3-H } & 0-109 & 34 \pm 2 & 0-109 & 35 \pm 3 & 0-109 & 15 \pm 1 \\ \text { WS-13 } & & & & & & \\ \text { 13-N } & 0-69 & 33 \pm 3 & 0-56 & 25 \pm 7 & 0-69 & {[8 \pm 4]} \\ 13-\mathrm{L} & 0-56 & 42 \pm 2 & 0-69 & 47 \pm 2 & 0-69 & 14 \pm 5 \\ 13-\mathrm{H} & 0-56 & 57 \pm 2 & 0-56 & 62 \pm 2 & 0-56 & 30 \pm 2 \\ & 56-116 & 44 \pm 7 & 56-116 & 44 \pm 7 & 56-116 & 10 \pm 3\end{array}$

${ }^{a}$ Rates in brackets denote that a significant linear regression $(\mathrm{P}<0.05)$ was not obtained with the available data; uncertainties in this table are standard errors derived from the linear regressions. 


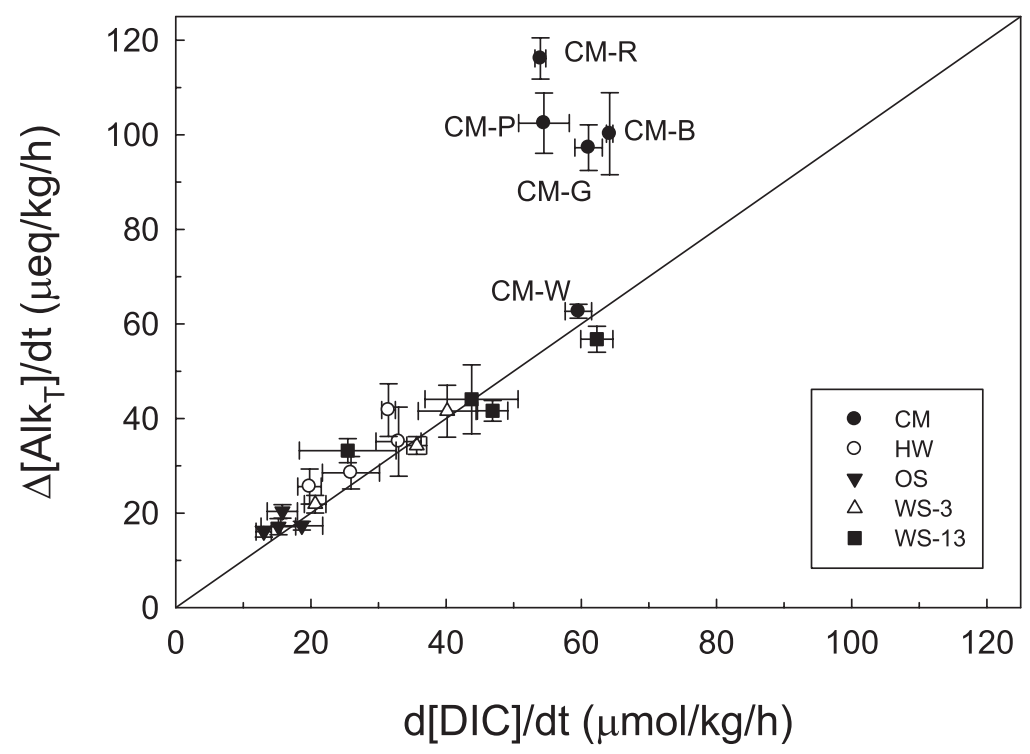

Figure 9. Production rates of alkalinity and DIC in all incubations (taken from Table 5). The solid line is the 1:1 line. Note that the CM incubations are individually labeled here to indicate the incubations that deviate from the 1:1 relationship shown here. Uncertainties are standard errors of the linear regressions.

\section{Discussions}

\section{a. Sources of alkalinity and DIC}

In the tropical, coastal seagrass sediments of Ban Pak Klok, Thailand, Holmer et al. (2001) observed that microbial respiration is closely coupled with organic matter production by the dominant seagrasses in these sediments, Cymodocea rotundata and Thalassia hemprichii; a similar observation was also made in Lower Laguna Madre sediments vegetated by T. testudinum (Jones et al., 2003). On the Bahamas Bank seagrasses are the dominant primary producers (Tussenboek et al., 2006) and in our previous study (Hu and Burdige, 2007), organic matter being remineralized in both bare oolitic sands and intermediate density seagrass sediments around LSI could be attributed to either a seagrass/detrital carbon mixture or seagrass carbon. Furthermore, in the carbonate dissolution/reprecipitation model proposed to explain the unusual enrichment of ${ }^{13} \mathrm{C}$ in the pore water DIC pool of dense seagrass sediments around LSI, seagrass carbon was assumed to be the sole type of organic carbon undergoing remineralization (see detailed discussions in $\mathrm{Hu}$ and Burdige, 2007). Therefore in the closed-system incubations described here, we will similarly assume that seagrass is the sole organic carbon source that contributes to the pore water DIC pool.

On the other hand, alkalinity changes can result from aerobic respiration, carbonate dissolution, and sulfate reduction. In the strict anoxic incubations (case 1$),\left[\mathrm{Ca}^{2+}\right]$ 


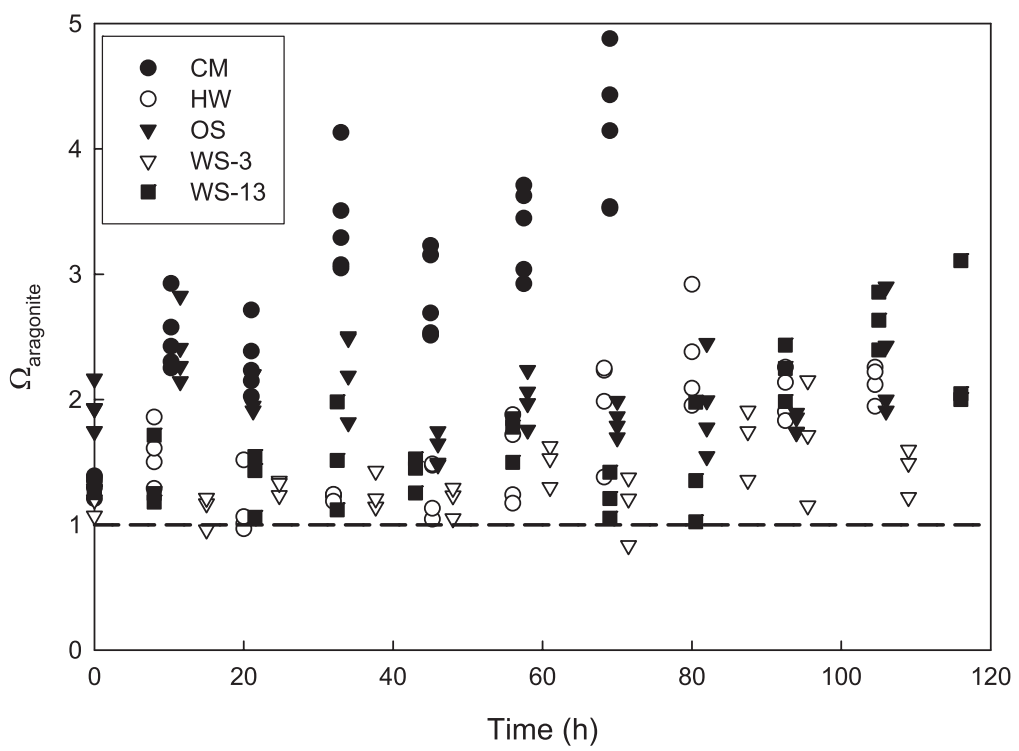

Figure 10. The pore water aragonite saturation index $\left(\Omega_{\text {arag }}\right)$ in all incubations. $\Omega_{\text {arag }}$ was calculated as the calcium carbonate ion concentration product (ICP) in the pore waters divided by the aragonite stoichiometric solubility constant $\left(K_{s p \text {-arag }}^{\prime}\right)$. The ion concentration product (ICP) for experimental time points was calculated using $\left[\mathrm{Ca}^{2+}\right]$ and $\left[\mathrm{CO}_{3}^{2-}\right]$, with the latter being determined with $\mathrm{pH}$ and DIC concentration data using the Excel ${ }^{\circledR}$ version of the program CO2SYS (Millero, pers. comm., Lewis and Wallace, 1998). The value of $K_{s p \text {-arag }}^{\prime}$ was calculated using the constants in Mucci (1983) at experimental temperatures and salinity.

increases were small (see Fig. 8), implying that net carbonate dissolution was minimal, and that pore water alkalinity increases here were almost exclusively derived from sulfate reduction.

To examine anoxic alkalinity production in case 1 incubations we used the following equation:

$\frac{1}{53}\left(\mathrm{CH}_{2} \mathrm{O}\right)_{106}\left(\mathrm{NH}_{3}\right)_{x}\left(\mathrm{H}_{3} \mathrm{PO}_{4}\right)_{y}+\mathrm{SO}_{4}^{2-}+\frac{x}{53} \mathrm{H}^{+} \rightarrow$

$$
2 \mathrm{HCO}_{3}^{-}+\mathrm{H}_{2} \mathrm{~S}+\frac{x}{53} \mathrm{NH}_{4}^{+}+\frac{y}{53} \mathrm{H}_{3} \mathrm{PO}_{4}
$$

Table 6. Isotopic composition (\%o) of seagrass and carbonate sediments.

$\begin{array}{lccc} & \delta^{13} \mathrm{C}_{\text {carbonate }} & \delta^{13} \mathrm{C}_{\text {Thalassia }} & \delta^{13} \mathrm{C}_{\text {Syringodium }} \\ \text { WS-3 } & 4.20 \pm 0.04 & -9.7 \pm 0.7 & -6.0 \pm 0.7 \\ \text { WS-13 } & 3.93 \pm 0.01 & -4.9 \pm 0.5 & -\end{array}$

Uncertainties are standard deviations of the measurements $(n=3)$. 

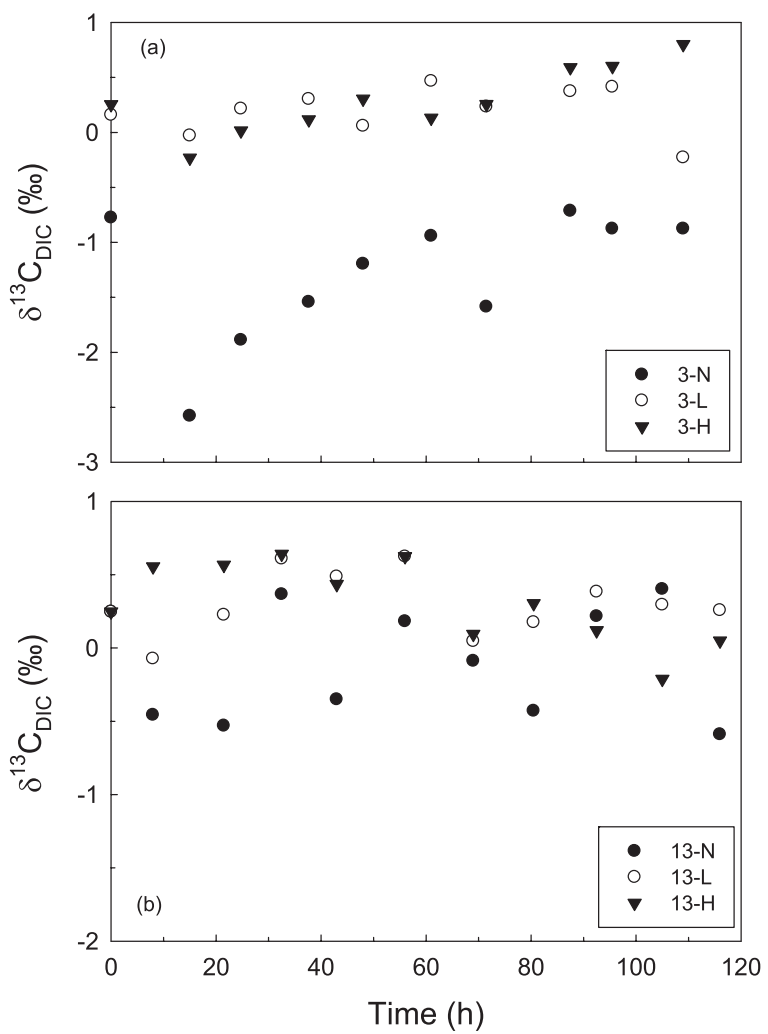

Figure 11. Co-evolution of pore water DIC $\delta^{13} \mathrm{C}$ and DIC concentration in (a) WS-3, and (b) WS-13 incubations.

where the value of $x$ is based on the average value of the seagrass $\mathrm{C} / \mathrm{N}$ molar ratio at each site (Table 7), and the value of $y$ is based on the seagrass $\mathrm{C} / \mathrm{P}$ molar ratio. In carbonate sediments such as those we have studied, the sediments are generally P-limited and the $\mathrm{C} / \mathrm{P}$ ratio may be $\sim 1000$ or higher (Hemminga and Duarte, 2000). From Eq. (7), we therefore see that one unit of sulfate reduction produces slightly more than two units of alkalinity:

Table 7. $\mathrm{C} / \mathrm{N}$ ratio of seagrasses at the sampling sites.

T. testudinum

$\begin{array}{lccccc}\text { Station ID } & \text { Leaf } & \text { Root } & \text { Leaf } & \text { Root } & x^{\text {a }} \\ \text { CM } & 16 & 30 & - & - & 4.6 \\ \text { HW } & 40 & 58 & - & - & 2.5 \\ \text { WS-3 } & 30 & 45 & 33 & 89 & 2.2 \\ \text { WS-13 } & 36 & 69 & - & - & 2.0\end{array}$

${ }^{\mathrm{a}} x=106 /(\mathrm{C} / \mathrm{N}$ molar ratio). See Eq. (7) for details. 


$$
\Delta A l k_{T} \cong \Delta A l k_{S}=2 \times \Delta \Sigma H_{2} S+\Delta\left[N H_{4}^{+}\right]=\left(2+\frac{x}{53}\right) \Delta \Sigma H_{2} S
$$

where $\Delta A l k_{\mathrm{S}}$ is the alkalinity produced by sulfate reduction, and alkalinity consumption from $\mathrm{P}$ remineralization is neglected.

In case 3 incubations, metabolic carbonate dissolution is driven solely by aerobic respiration, and one unit of organic carbon oxidation also yields slightly more than two units of carbonate alkalinity, if the strong acids $\left(\mathrm{HNO}_{3}\right.$ and $\left.\mathrm{H}_{3} \mathrm{PO}_{4}\right)$ produced during aerobic respiration by organic $\mathrm{N}$ and $\mathrm{P}$ remineralization also dissolve sedimentary carbonate. However in the discussion below we will neglect the contribution of this strong acid production to carbonate dissolution, given the high seagrass C/N/P ratio (see Table 7 and the discussion above).

In case 2 studies, where both aerobic and anaerobic respiration occur, the following equation was used to differentiate the alkalinity sources (cf. Berner et al., 1970):

$$
\Delta A l k_{T}=\Delta A l k_{C}+\Delta A l k_{S}
$$

where again $\Delta A l k_{T}$ is the change in total (measured) alkalinity, $\Delta A l k_{\mathrm{S}}$ is defined above (see Eq. 8), and $\Delta A l k_{\mathrm{C}}$ is then the alkalinity produced by aerobic, metabolic carbonate dissolution (rxns. 1-3). The determination of $\Delta A l k_{C}$ from experimental data is discussed in the next section.

\section{b. Reaction stoichiometry}

One of the goals of this work was to more critically examine the $\mathrm{Ca}^{2+}$ content of the carbonate phase undergoing dissolution. Here plots of $\Delta \mathrm{Alk}_{\mathrm{C}}$ versus $\Delta\left[\mathrm{Ca}^{2+}\right]$ in individual incubations can be used, with the $\mathrm{Ca}$ content of the apparent carbonate phase that is dissolving being equal to $2 \mathrm{x}\left(\mathrm{d} \Delta\left[\mathrm{Ca}^{2+}\right] / \mathrm{d} \Delta \mathrm{Alk}_{\mathrm{C}}\right)$, where $\mathrm{d} \Delta\left[\mathrm{Ca}^{2+}\right] / \mathrm{d} \Delta \mathrm{Alk}_{\mathrm{C}}$ is the slope of the regression line through the data. In case 2 studies, $\Delta \Sigma \mathrm{H}_{2} \mathrm{~S}$ results and Eq. (8) can be used to calculate $\Delta \mathrm{Alk}_{\mathrm{S}}$, and then $\Delta \mathrm{Alk}_{\mathrm{C}}$ can be calculated with Eq. (9). In case 3 studies where there was no sulfate reduction, $\Delta \mathrm{Alk}_{\mathrm{S}}=0$ and $\Delta \mathrm{Alk}_{\mathrm{C}}=\Delta \mathrm{Alk}_{\mathrm{T}}$.

In all $\mathrm{HW}$, OS, and $\mathrm{CM}$ incubations except the CM-W incubation, $\mathrm{Ca}^{2+}$ and $\mathrm{Alk}_{\mathrm{C}}$ concentration changes were relatively low due to either low overall rates of sediment processes (e.g., the OS incubations) or high rates of sulfate reduction versus aerobic respiration (e.g., all CM incubations except $\mathrm{CM}-\mathrm{W}$ ). As a result, regressions of $\Delta\left[\mathrm{Ca}^{2+}\right]$ versus $\Delta \mathrm{Alk}_{\mathrm{C}}$ for these regressions yielded slopes with large errors and high $\mathrm{P}$ values $(>0.05)$. Therefore these results are not included in the discussion here. Also, neither the $3-\mathrm{N}$ nor the $13-\mathrm{N}$ incubation yielded significant amounts of $\mathrm{Ca}^{2+}$ production $\left(\mathrm{d} \Delta\left[\mathrm{Ca}^{2+}\right] /\right.$ $\mathrm{dt} \approx 0$, Table 5), which is indicative of no net carbonate dissolution, consistent with the trends discussed in Section 3a.i for such case 1 incubations. These results were therefore similarly not used in the calculations described here.

In the remaining incubations (CM-W, 13-L, 13-H, 3-H and 3-L), regressions of $\Delta\left[\mathrm{Ca}^{2+}\right.$ ] versus $\Delta \mathrm{Alk}_{\mathrm{C}}$ yielded slopes that ranged from 0.32 to 0.47 (Fig. 12 and Table 8), with a 

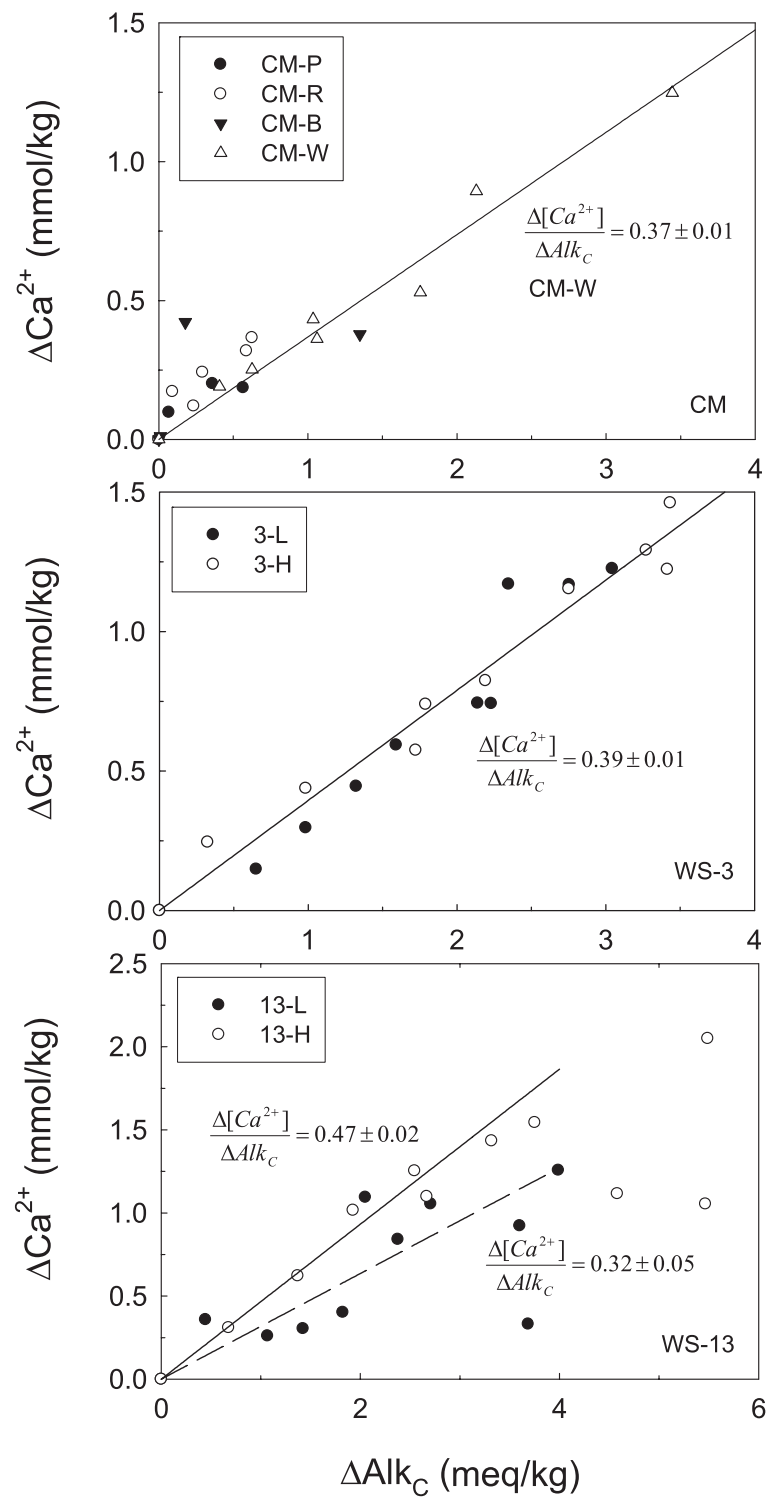

Figure 12. The regression of $\Delta\left[\mathrm{Ca}^{2+}\right]$ vs. $\Delta \mathrm{Alk}_{\mathrm{C}}$ for the CM, WS-3 and WS-13 incubations. Since the $y$-intercepts of these linear regressions are not significantly different from zero, the regression lines were all forced through the origin. Note that in the CM incubations, only the data from the CM-W incubation were used to generate the regression line. See the text and Table 8 for details.

weighted average of $0.39 \pm 0.01$. Thus the apparent dissolving carbonate phase in these incubations had a Mg-content of $\sim 22$ mole\% (i.e., $(1-0.39) \times 2=0.22$ ), broadly consistent with HMC being the dissolving carbonate phase. Solubility considerations 
Table 8. Composition of the apparent dissolving phase in the CM-W, WS-3 and WS-13 incubations $^{\mathrm{a}}$.

$\begin{array}{ccccc} & \mathrm{CM}-\mathrm{W} & 3-\mathrm{L} \& 3-\mathrm{H}^{\mathrm{b}} & 13-\mathrm{L}^{\mathrm{c}} & 13-\mathrm{H}^{\mathrm{c}} \\ \mathrm{d} \Delta\left[\mathrm{Ca}^{2+}\right] / \mathrm{d} \Delta \mathrm{Alk}_{\mathrm{C}} & 0.37 \pm 0.01 & 0.39 \pm 0.01 & 0.32 \pm 0.05 & 0.47 \pm 0.02 \\ \mathrm{r}^{2} & 0.97 & 0.97 & 0.76 & 0.98 \\ \mathrm{P} & <0.0001 & <0.0001 & <0.001 & <0.0001 \\ \text { mole\% } \mathrm{Mg} & 26 & 21 & 36 & 7\end{array}$

${ }^{a}$ Uncertainties are standard errors obtained from linear regressions (Fig. 13).

${ }^{\mathrm{b}}$ In these incubations the regression slopes of $\Delta\left[\mathrm{Ca}^{2+}\right]$ versus $\Delta \mathrm{Alk}_{\mathrm{C}}$ for each incubation were not significantly different from each other (Student's t-test, $\mathrm{P}>0.05$ ). Therefore the pooled data were used to calculate a combined value of $\mathrm{d} \Delta\left[\mathrm{Ca}^{2+}\right] / \mathrm{d} \Delta \mathrm{Alk}_{\mathrm{C}}$.

${ }^{\mathrm{c}}$ In the WS-13 incubations, the first 6 data points $(0-56 \mathrm{hrs})$ for both oxic incubations showed a good linear relationship between $\Delta\left[\mathrm{Ca}^{2+}\right]$ and $\Delta \mathrm{Alk}_{\mathrm{C}}$ and were used in these regressions. This approach is consistent with the isotope mass balance calculations in the Section $4 c$ (see note e in Table 9), and $56 \mathrm{hrs}$ also represents the time at which the $\mathrm{O}_{2}$ gas pressure was reduced from 20 psi to 10 psi (see note $\mathrm{c}$ in Table 3 ).

(Section 3c.iv and Fig. 10) further suggest that a carbonate phase(s) with a solubility greater than or similar to aragonite (e.g., HMC) was dissolving in these incubations in response to metabolic $\mathrm{CO}_{2}$ production (see Morse and Mackenzie, 1990, or Morse et al., 2006, for discussions of HMC vs. calcite or aragonite solubility).

In contrast, the Mg content of the HMC in the CM, WS-3 and WS-13 sediments determined using XRD techniques was much lower than that calculated from the pore water results $(\sim 12-13$ mole\% vs. $\sim 22$ mole\% Mg; see Tables 2 and 8$)$. Two possible reasons may explain this apparent discrepancy. The first is that a more soluble HMC with a higher Mg content ( $\sim 22$ mole $\% \mathrm{Mg}$ ) was actually dissolving, since in natural carbonates HMC solubility increases with increasing Mg content (Plummer and Mackenzie, 1974; Bischoff et al., 1987, 1993). Furthermore, because the XRD spectra of these carbonate sediments generally showed a broadened 104 peak as compared to that obtained with pure biogenic calcite standards, the HMC in these sediments was possibly a mixture of carbonates with a range of $\mathrm{Mg}$ contents such that the average value was $\sim 12$ mole\% (Berner, 1966). However, when comparing our results with tabulated results in the literature of the Mg content of HMC in Bahamian sediments (e.g., Morse et al., 1985), the $\mathrm{Mg}$ content of HMC based on the pore water data is at the high end of this range. At the same time, histograms of the $\mathrm{Mg}$ content of $\mathrm{HMC}$ in shallow water carbonate sediments in general show that the average $\mathrm{Mg}$ content of these sediments is $\sim 13-14$ mole $\%$ (Morse and Mackenzie, 1990), with no sediments they examined having a Mg content greater than 18 mole\%.

Alternatively, if $\mathrm{HMC}$ with $\sim 12$ mole $\% \mathrm{Mg}$ was indeed dissolving, then a secondary carbonate phase with a lower Mg content may be reprecipitating (e.g., Rude and Aller, 1991). Such a scenario could then sustain a disproportional increase in $\left[\mathrm{Ca}^{2+}\right]$ relative to 
Table 9. Values of $\delta^{13} \mathrm{C}_{\text {added }}$ for the WS-3 and WS-13 incubations.

$\begin{array}{cccccc} & 3-\mathrm{N} & 3-\mathrm{L} \& 3-\mathrm{H}^{\mathrm{c}} & 13-\mathrm{N}^{\mathrm{d}} & 13-\mathrm{L}^{\mathrm{e}} & 13-\mathrm{H}^{\mathrm{e}} \\ \delta^{13} \mathrm{C}_{\text {added }} \mathrm{a}^{2} & 2.73 \pm 0.47 & 1.25 \pm 0.18 & -0.3 \pm 1.2 & 1.20 \pm 0.32 & 0.74 \pm 0.17 \\ \mathrm{r}^{2} & 0.83 & 0.77 & 0.02 & 0.78 & 0.82 \\ \mathrm{P} & <0.001 & <0.0001 & >0.05 & <0.05 & <0.05 \\ \delta^{13} \mathrm{C}_{\mathrm{OM}}^{\mathrm{b}} & 2.73 \pm 0.47 & -2.00 \pm 0.71 & -0.3 \pm 1.2 & -1.53 \pm 0.64 & -2.45 \pm 0.34\end{array}$

${ }^{\text {a}}$ Uncertainties are standard errors obtained from the linear regressions in Figures 12-13.

${ }^{\mathrm{b}}$ For the oxic (case 3) incubations (3-L \& 3-H, 13-L and $\left.13-\mathrm{H}\right) \delta^{13} \mathrm{C}_{\mathrm{OM}}$ values were calculated using a 1:1 mixing ratio between organic carbonate and carbonate carbon (see Eq. 10 and related discussions). For the anoxic incubations, the apparent lack of significant carbonate dissolution implies that $\delta^{13} \mathrm{C}_{\mathrm{OM}}$ is roughly equal to $\delta^{13} \mathrm{C}_{\text {added }}$.

${ }^{\mathrm{c}}$ In the WS-3 incubations, the calculated $\delta^{13} \mathrm{C}_{\text {added }}$ values in both the $3-\mathrm{L}$ and the $3-\mathrm{H}$ incubations were not significantly different from each other (ANCOVA, $\mathrm{P}>0.05$ ), therefore the data from these incubations were pooled together and a single $\delta^{13} \mathrm{C}_{\text {added }}$ value was calculated for the pooled data set.

${ }^{\mathrm{d}}$ This regression was not significant although the calculated $\delta^{13} \mathrm{C}_{\text {added }}$ was used for comparative purposes.

${ }^{\mathrm{e}}$ Data from only the first half $(0-56 \mathrm{hr})$ of these incubations were used here (see note $\mathrm{c}$ in Table 3 for details).

the $\mathrm{Ca} / \mathrm{Mg}$ ratio of the sediment $\mathrm{HMC}$. These two possible explanations will be revisited in Section $4 \mathrm{~d}$ after discussing the stable isotope mass balance in Section $4 \mathrm{c}$.

\section{c. Stable carbon isotope mass balance}

In our previous work (Hu and Burdige, 2007) we showed that the $\delta^{13} \mathrm{C}$ of pore water DIC could be used to not only differentiate between carbon sources that contribute to the pore water DIC pool (see Eqs. 1-3), but could also provide evidence for coupled carbonate dissolution/reprecipitation. In this section we will use the stable isotope data from these incubation experiments to examine these same processes.

Following the procedure in $\mathrm{Hu}$ and Burdige (2007), the $\delta^{13} \mathrm{C}$ of the DIC being added to the pore waters of these incubations $\left(\delta^{13} \mathrm{C}_{\text {added }}\right)$ was calculated using a linear regression of $\delta^{13} \mathrm{C}$ - DIC vs. DIC (also see discussions in Sayles and Curry, 1988; Martin et al., 2000; note that $\delta^{13} \mathrm{C}$ - DIC is the $\delta^{13} \mathrm{C}$ of the pore water DIC multiplied by the DIC concentration). The values of $\delta^{13} \mathrm{C}_{\text {added }}$ derived from these linear regressions are shown in Table 9 and Figures 13-14.

In the absence of coupled dissolution/reprecipitation one unit of $\mathrm{CO}_{2}$ production under oxic conditions should result in approximately the same amount of carbonate dissolution (ignoring the minor amount of carbonate dissolution caused by nitric and phosphoric acid productions; see Section $4 \mathrm{a}$ ). Therefore $\delta^{13} \mathrm{C}_{\text {added }}$ can be described using the following equation:

$$
\delta^{13} C_{\text {added }}=f_{C} \delta^{13} C_{C}+f_{O M} \delta^{13} C_{O M}
$$




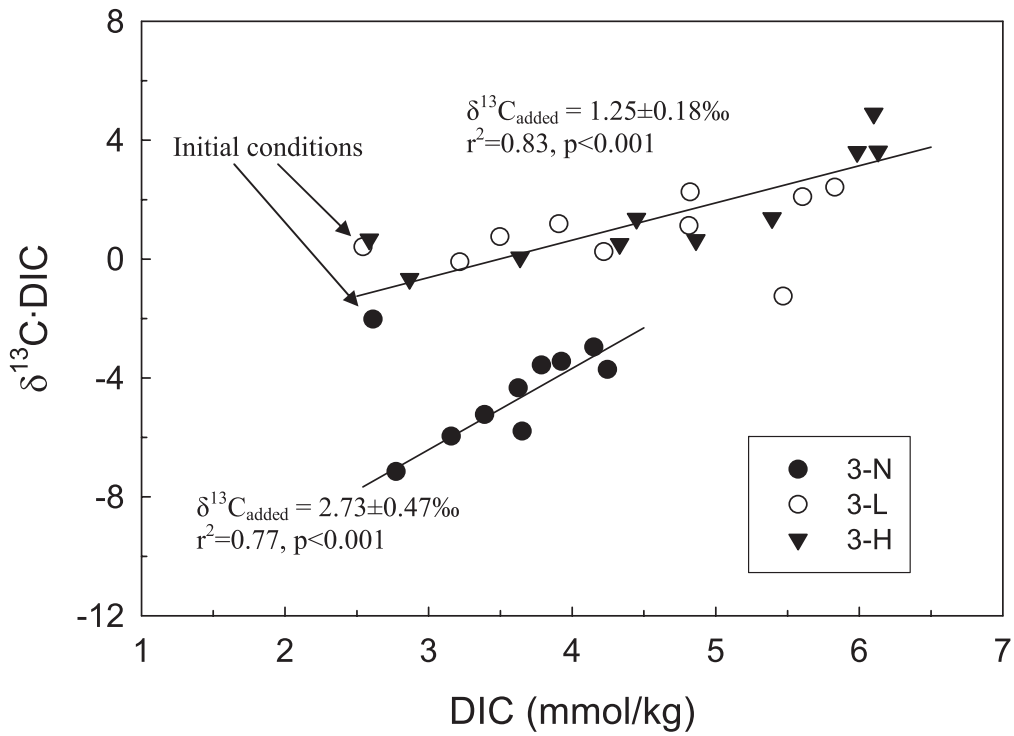

Figure 13. Regression of $\delta^{13} \mathrm{C} \cdot \mathrm{DIC}$ vs. DIC in the WS-3 incubations. Note that the regression lines did not include the initial data points, to account for the equilibration of the sediment-water mixture after the initial setup of the experiment. The data from the 3-L and 3-H incubations were pooled together since regression slopes $\left(\delta^{13} \mathrm{C}_{\text {added }}\right)$ of each individual incubation were not statistically different from each other, although both were lower than that of the anoxic incubation (ANCOVA test, $\mathrm{P}<0.05$, and $\delta^{13} \mathrm{C}_{\text {added-3-L }}=\delta^{13} \mathrm{C}_{\text {added-3-H }}<\delta^{13} \mathrm{C}_{\text {added-3-N }}$ ).

where the $f$ values are the fractional DIC contributions from carbonate dissolution (subscript $C$ ) and organic matter oxidation (subscript $O M$ ) and, based on Eqs. (1)-(3), $f_{C}=$ $f_{O M}=50 \%$.

Using Eq. (10), the calculated values of $\delta^{13} C_{\text {added }}$ (Table 9) and the measured values of $\delta^{13} \mathrm{C}_{\mathrm{C}}$ in WS-3 and WS-13 sediments (Table 6) can be used to back-calculate $\delta^{13} \mathrm{C}_{\mathrm{OM}}$ in the WS-3 and WS-13 L and $\mathrm{H}$ incubations. These results are also listed in Table 9. Similarly, in the anoxic (3-N and 13-N) incubations the absence of any carbonate dissolution (see Section $4 \mathrm{~b}$ ) implies that $\delta^{13} \mathrm{C}_{\mathrm{OM}} \approx \delta^{13} \mathrm{C}_{\text {added }}$, based solely on the addition of DIC to the pore waters of these incubations by sulfate reduction.

However an examination of the results in Table 9 show that the values of $\delta^{13} \mathrm{C}_{\mathrm{OM}}$ calculated using the approach outlined above were all greater than the $\delta^{13} \mathrm{C}$ values of seagrasses at the respective sites (Table 6), as well the $\delta^{13} \mathrm{C}$ values of any other types of natural organic carbon that might be found in these environments (Rasmussen et al., 1990; Hofmann et al., 2000). Similar observations in dense seagrass sediments around LSI were explained by a coupled dissolution/reprecipitation process (Fig. 15; Hu and Burdige, 2007), and in the following discussion, the closed system dissolution/reprecipitation model presented in this paper will be applied to the results from these incubations.

In this model several assumptions are explicitly made: (1) no isotope fractionation 

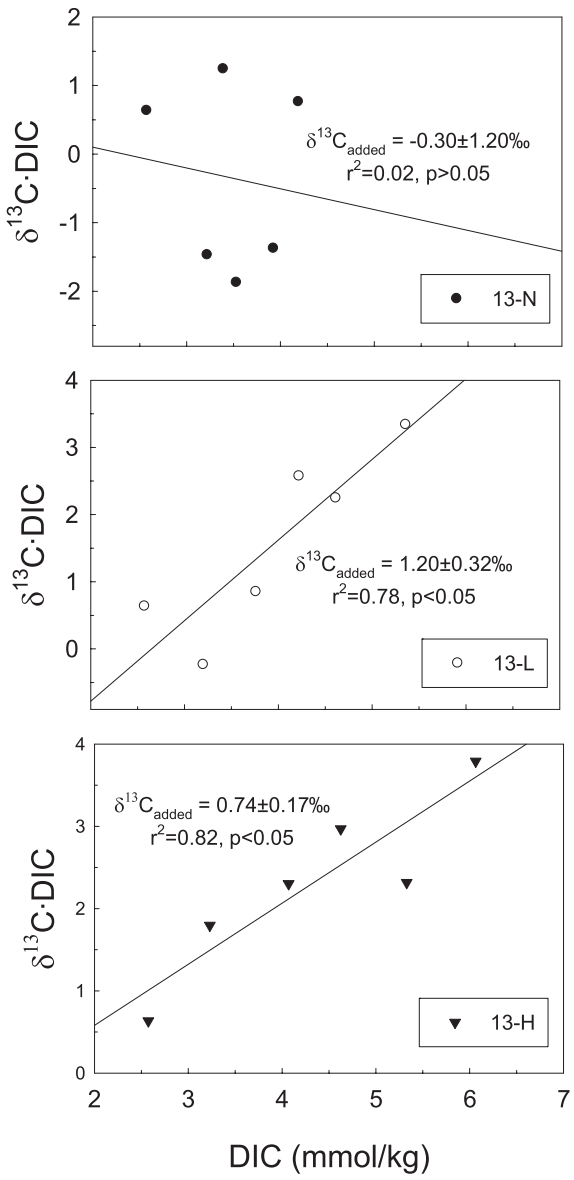

Figure 14. Regression of $\delta^{13} \mathrm{C} \cdot \mathrm{DIC}$ vs. DIC in the WS-13 incubations. In the $13-\mathrm{N}$ incubation, the regression slope was not significant (see Table 9).

occurs during carbonate dissolution (Martin et al., 2000); (2) reprecipitation of the secondary carbonate occurs under equilibrium conditions (Patterson and Walter, 1994); (3) isotopic fractionation during reprecipitation $\left(\epsilon_{\text {calcite-Hсо3 }}{ }^{-}\right)$equals $0.9 \%$ (Rubinson, 1969$)$; and (4) diffusion processes that causes isotope gradients on mineral surfaces are negligible, i.e., the pore waters are isotopically homogeneous so that the secondary carbonate produced at any given time has the same isotopic composition throughout the incubation vial.

For the aerobic incubations, carbonate dissolution and reprecipitation in the model equations can be expressed as:

$$
\frac{d\left[{ }^{13} C\right]}{d t}=r_{\text {diss }} \times F_{C}+r_{o x} \times F_{O M}-r_{r p} \times F_{r p}
$$




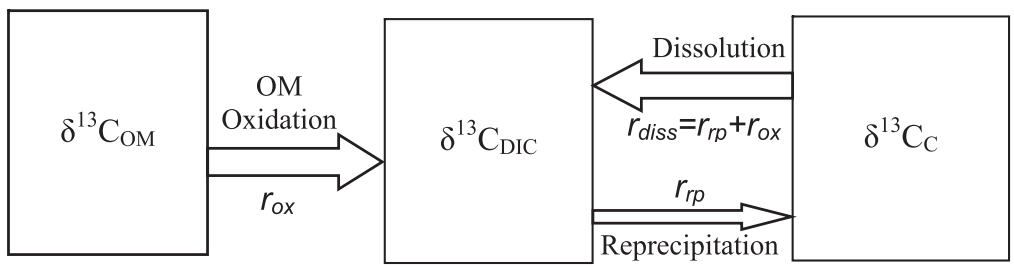

Figure 15. Carbonate dissolution/reprecipitation model. The dissolution rate $\left(r_{\text {diss }}\right)$ shown here represents the "gross" dissolution rate equal to the sum of the metabolic dissolution rate $\left(r_{o x}\right.$; driven by $\mathrm{CO}_{2}$ release) and the reprecipitation rate $\left(r_{r p}\right)$. See Hu and Burdige (2007) for details.

$$
\frac{d\left[{ }^{12} C\right]}{d t}=r_{d i s s} \times\left(1-F_{C}\right)+r_{o x} \times\left(1-F_{O M}\right)-r_{r p} \times\left(1-F_{r p}\right)
$$

where: $r$ is the rate of a reaction; the subscripts diss, $o x$, and $r p$ represent gross dissolution, organic matter oxidation and reprecipitation; and $F_{\mathrm{i}}$ is the ${ }^{13} \mathrm{C}$ isotopic abundance of the reactants carbonate $(i=C)$ and organic carbon $(i=O M)$, and the secondary carbonate product $(i=r p)$. Based on mass balance considerations,

$$
F_{i}=\frac{R_{i}}{1+R_{i}}
$$

where $R_{i}$ is the isotopic ratio $\left({ }^{13} \mathrm{C} /{ }^{12} \mathrm{C}\right)$ in the appropriate phase. Based on assumption (3) above, the isotopic ratio of the reprecipitated carbonate $\left(R_{r p}\right)$ is related to that of the pore water DIC $\left(R_{p w}\right)$ by:

$$
R_{r p}=\alpha \times R_{p w}
$$

in which the equilibrium isotope fractionation factor $\alpha=\mathrm{e}^{(\epsilon+1)}=1.009$. The "net" dissolution rate $\left(r_{\text {diss }}^{\prime}\right)$ equals $r_{o x}$ (see Table 10 and $\mathrm{Hu}$ and Burdige, 2007), and therefore

$$
r_{o x}=r_{d i s s}-r_{r p}
$$

Finally, given the stoichiometry of rxn. (3), $r_{o x}$ can be calculated through the regression of DIC versus incubation time:

$$
r_{o x}=r_{d i s s}^{\prime}=\frac{1}{2} \frac{d[D I C]}{d t}
$$

Note that values of $r_{o x}$ calculated using alkalinity production rates agreed well with DIC-derived rates (Table 5).

In the two anoxic incubations (3-N and $13-\mathrm{N}) \Delta\left[\mathrm{Ca}^{2+}\right]$ results suggested that net carbonate dissolution was negligible in these incubations (see Section $4 \mathrm{~b}$ ). Thus here 
Table 10. Reaction rates and secondary carbonate compositions in WS-3 and WS-13 experiments ${ }^{\mathrm{a}}$.

$\begin{array}{cccccc}\begin{array}{c}\text { Rate } \\ \left(\mu \mathrm{mol} \mathrm{kg}{ }^{-1} \mathrm{~h}^{-1}\right)\end{array} & 3-\mathrm{N} & 3-\mathrm{L} \& 3-\mathrm{H}^{\mathrm{g}} & 13-\mathrm{N} & 13-\mathrm{L} & 13-\mathrm{H} \\ r_{o x}^{\mathrm{b}} & 14 \pm 2 & 16 \pm 1 & 25 \pm 5 & 24 \pm 1 & 31 \pm 1 \\ r_{\text {diss }}^{\prime}{ }^{\prime} & 0 & 16 \pm 1 & 0 & 24 \pm 1 & 31 \pm 1 \\ r_{r p}{ }^{\mathrm{c}} & 32 \pm 5 & 33 \pm 6 & 39 \pm 47 & 32 \pm 23 & 28 \pm 14 \\ r_{\text {diss }}{ }^{\mathrm{d}} & 32 \pm 5 & 49 \pm 6 & 39 \pm 47 & 56 \pm 23 & 59 \pm 14 \\ R_{r x}^{\mathrm{e}} & - & 2.1 \pm 0.5 & - & 1.4 \pm 0.6 & 0.9 \pm 0.5 \\ x^{\mathrm{f}} & 0.93 \pm 0.31 & 0.92 \pm 0.42 & 0.61 \pm 1.94 & 1.06 \pm 1.02 & 0.82 \pm 0.99\end{array}$

${ }^{\text {a } U n c e r t a i n t i e s ~ a r e ~ s t a n d a r d ~ e r r o r s ~ f r o m ~ e i t h e r ~ l i n e a r ~ r e g r e s s i o n s ~}\left(r_{o x}\right)$ or model calculations $\left(r_{r p}\right.$, $R_{r x}$, and $x$ ).

${ }^{\mathrm{b}}$ Calculated with the pore water data from these incubations as discussed in the text.

${ }^{\mathrm{c}}$ Used as an adjustable fitting parameter in the model as discussed in the text.

${ }^{\mathrm{d}}$ In the oxic incubations, calculated using Eq. (15); in the anoxic incubations, assumed to be equal to $r_{\mathrm{rp}}$ (see the text for details).

${ }^{\mathrm{e}} R_{r x}$ is the ratio of carbonate reprecipitation and net dissolution rates $\left(r_{r p} / r_{d i s s}^{\prime}\right)$. In the absence of net dissolution in the 3-and 13-N experiments, $R_{\mathrm{rx}}$ can not be calculated.

${ }^{\mathrm{f}} \mathrm{x}$ is the calculated $\mathrm{Ca}$ content in the secondary carbonate phase (see Eq. 21). Errors reported here were determined by propagation of errors through the calculation of $x$.

$\mathrm{g}_{r_{o x}}$ for 3-L and 3-H was calculated on pooled DIC data because the DIC production rates from both incubations (see Table 5) were not significantly different from each other (ANCOVA test, $\mathrm{P}>0.05)$.

net dissolution $\left(r_{\text {diss }}^{\prime}\right)$ was assumed to be equal to 0 and any carbonate dissolution must be balanced by reprecipitation (i.e., $r_{\text {diss }}=r_{r p}$ ). As a result, Eqs. (11)-(12) become:

$$
\begin{gathered}
\frac{d\left[{ }^{13} C\right]}{d t}=r_{r p} \times F_{C}+r_{o x} \times F_{O M}-r_{r p} \times F_{r p} \\
\frac{d\left[{ }^{12} C\right]}{d t}=r_{r p} \times\left(1-F_{C}\right)+r_{o x} \times\left(1-F_{O M}\right)-r_{r p} \times\left(1-F_{r p}\right)
\end{gathered}
$$

and $r_{o x}$ is:

$$
r_{o x}=\frac{d[D I C]}{d t}
$$

Both the oxic model (Eqs. 11-16) and the anoxic model (Eqs. 17-19) were solved using the $4^{\text {th }}$ order Runge-Kutta method in the program Stella ${ }^{\circledR}$.

Values of $r_{o x}$ and $r_{\text {diss }}^{\prime}$ that were used in the solutions to these model equations were taken from Table 10, and values of $F_{C}$ and $F_{O M}$ were calculated using eq. (13) and results are in Table 6. $F_{r p}$ was calculated as discussed above using Eq. (14). The data for each incubation were therefore fit to the appropriate model by adjusting values of $r_{r p}$ to obtain the calculated $\delta^{13} \mathrm{C}_{\text {added }}$ value for that incubation. These values of $r_{r p}$ are also shown in Table 10, as are the values of $r_{\text {diss }}$ calculated using Eq. (15). 

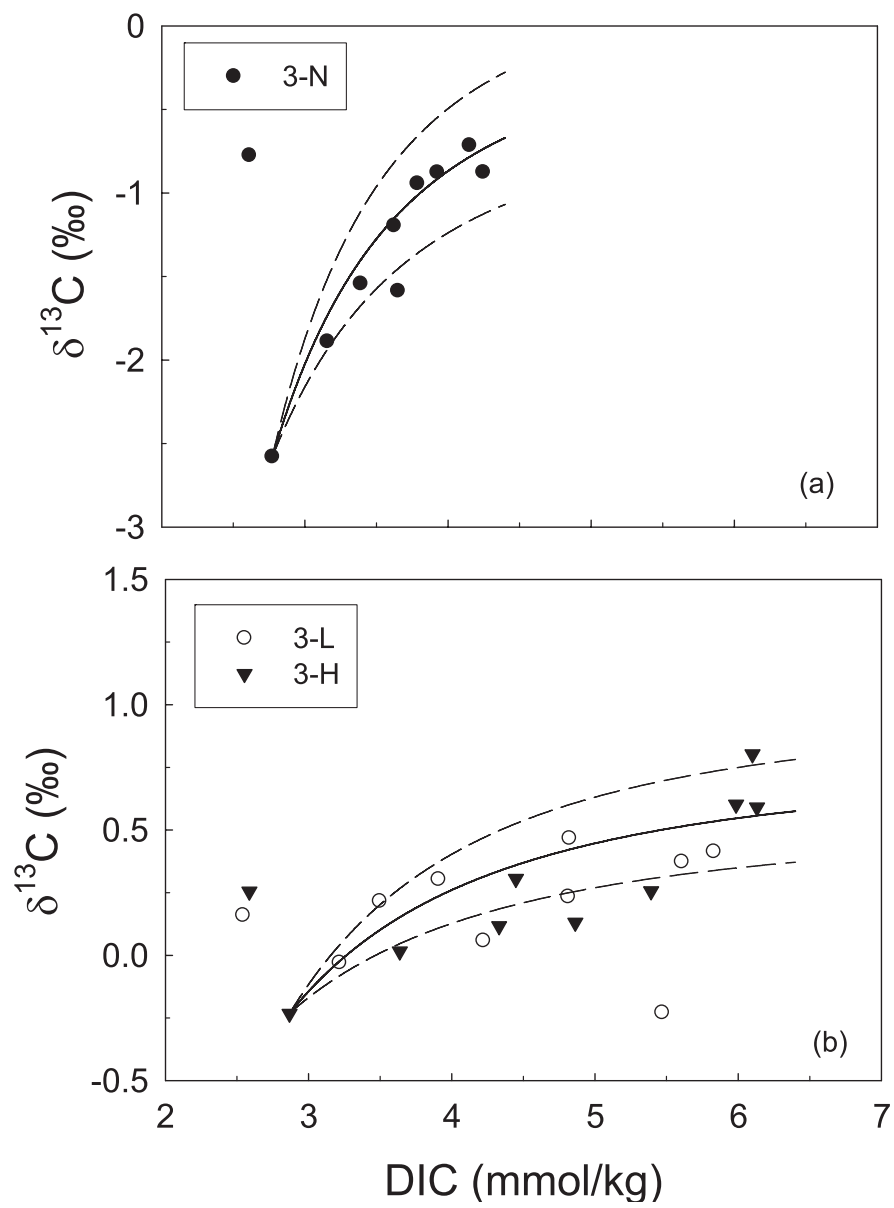

Figure 16. Results of the carbonate dissolution/reprecipitation model applied to the WS-3 incubations. The solid lines represent model results obtained with an $r_{r p}$ value that predicts the best-fit values of $\delta^{13} \mathrm{C}_{\text {added }}$ from Figure 13. The dashed lines are model results based on the upper and lower uncertainties (95\% confidence interval) of $\delta^{13} \mathrm{C}_{\text {added }}$.

The co-evolution of pore water DIC concentration and the $\delta^{13} \mathrm{C}$ of the DIC in these incubations, and these best-fit model results, are shown in Figures 16 and 17. As can be seen, the model does a reasonably good job of reproducing these data. More importantly, by constraining the rates of gross dissolution $\left(r_{\text {diss }}\right)$ and reprecipitation $\left(r_{r p}\right)$ with these model results we can now re-examine the discrepancy described in Section $4 \mathrm{~b}$ between the composition of HMC in these sediments determined by XRD (Table 2), and the composition of the HMC phase that is apparently dissolving based on the pore water results (Table 8). 

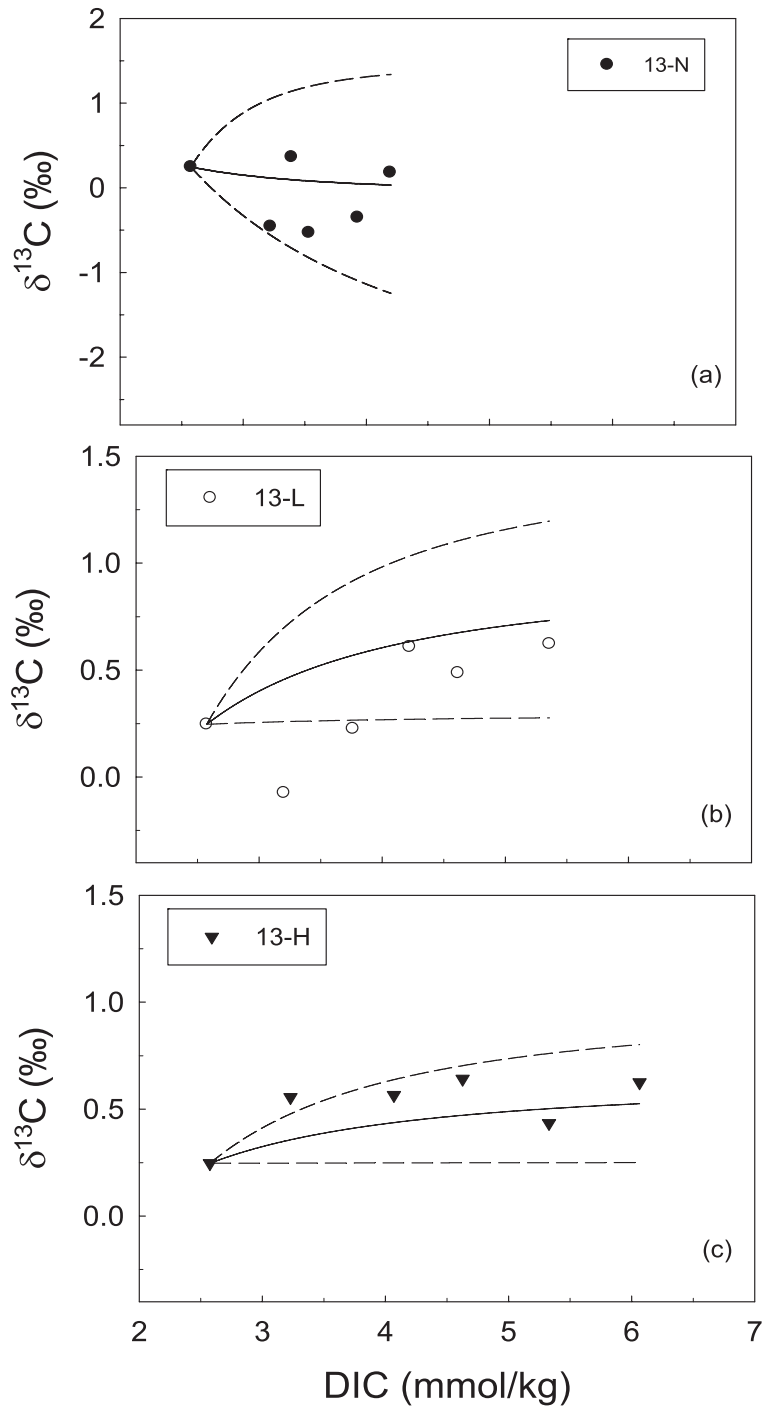

Figure 17. Results of the carbonate dissolution/reprecipitation model applied to the WS-13 incubations. The solid lines represent model results obtained with an $r_{r p}$ value that predicts the best-fit value of $\delta^{13} \mathrm{C}_{\text {added }}$ from Figure 14. The dashed lines are the model results based on the upper and lower uncertainties (95\% confidence interval) of $\delta^{13} \mathrm{C}_{\text {added }}$.

\section{d. The composition of the secondary carbonate phase}

i. Oxic incubations. If we express the chemical composition of the reprecipitated carbonate phase as $\mathrm{Ca}_{\mathrm{x}} \mathrm{Mg}_{(1-\mathrm{x})} \mathrm{CO}_{3}$, then the dissolution and reprecipitation processes can be written as follows: 


$$
\begin{gathered}
\mathrm{Ca}_{0.88} \mathrm{Mg}_{0.12} \mathrm{CO}_{3}+\mathrm{CO}_{2}+\mathrm{H}_{2} \mathrm{O} \stackrel{r_{\text {dits }}}{\longrightarrow} 0.88 \mathrm{Ca}^{2+}+0.12 \mathrm{Mg}^{2+}+2 \mathrm{HCO}_{3}^{-} \\
x \mathrm{Ca}^{2+}+(1-x) \mathrm{Mg}^{2+}+2 \mathrm{HCO}_{3}^{-} \stackrel{r_{\text {rp }}}{\rightarrow} \mathrm{Ca}_{x} \mathrm{Mg}_{(1-x)} \mathrm{CO}_{3}+\mathrm{H}_{2} \mathrm{O}+\mathrm{CO}_{2}
\end{gathered}
$$

Based on these equations the concentration changes for $\mathrm{Ca}^{2+}$ and alkalinity are given by:

$$
\begin{gathered}
\frac{d \Delta\left[\mathrm{Ca}^{2+}\right]}{d t}=r_{d i s s} \times 0.88-r_{r p} \times x \\
\frac{d \Delta A l k}{d t}=2 r_{d i s s}-2 r_{r p}
\end{gathered}
$$

and the linear regression of $\Delta\left[\mathrm{Ca}^{2+}\right]$ versus $\Delta$ Alk will have a slope equal to:

$$
\frac{d \Delta\left[\mathrm{Ca}^{2+}\right]}{d \Delta A l k}=\frac{r_{\text {diss }} \times 0.88-r_{r p} \times x}{2\left(r_{\text {diss }}-r_{r p}\right)}
$$

With the values of $r_{\text {diss }}$ and $r_{r p}$ in Table 10 and the values of $\mathrm{d} \Delta\left[\mathrm{Ca}^{2+}\right] / \mathrm{d} \Delta$ Alk in Table 8 (also see Section $4 \mathrm{~b}$ ), we can then use Eq. (24) to solve for $x$, the Ca content of the secondary carbonate phase that is being reprecipitated.

ii. Anoxic incubations. There appeared to be minimal net carbonate dissolution in the 3-N and 13-N incubations (Section 4b), and in the model calculations with these data we explicitly assumed that $r_{\text {diss }}^{\prime}$ was equal to zero. This assumption then implies that any net alkalinity change comes from sulfate reduction (and not carbonate dissolution), indicating that Eq. (23) is not valid for these incubations. However Eq. (22) does allow us to solve for $x$ in these incubations, using the values of $\mathrm{d} \Delta\left[\mathrm{Ca}^{2+}\right] / \mathrm{dt}$ in Table 5 and the values of $r_{\text {diss }}$ and $r_{r p}$ in Table 10.

iii. Results. Although estimates of $x$ from individual incubations have relatively large errors (Table 10), a weighted average of all these results (each value weighted by the inverse of its variance; Bevington and Robinson, 1969) yields an $x$ value of $0.92 \pm 0.23$. This implies that the secondary phase which forms in these sediments was likely HMC with $\sim 8$ mole\% $\mathrm{Mg}$ (i.e., $\mathrm{Ca}_{0.92} \mathrm{Mg}_{0.08} \mathrm{CO}_{3}$ ), versus an $\mathrm{HMC}$ starting material with $\sim 12$ mole $\% \mathrm{Mg}$. Although some caution must be taken in the interpretation of these calculations, they agree with the composition of $\mathrm{HMC}$ overgrowths $(\sim 8$ mole $\% \mathrm{Mg})$ which formed on the surface of Iceland spar (crystallized calcite mineral) buried in Bahamian sediments (Mucci and Morse, 1983; Morse and Mucci, 1984).

Furthermore, when our results are examined in the context of the discussion in Section $4 \mathrm{~b}$, it appears that carbonate reprecipitation in these sediments produces a secondary phase 
with only a slightly lower $\mathrm{Mg}$ content than that of the starting material. These results therefore suggest that HMC dissolution/reprecipitation likely occurs in the sediments we studied as a result of "Ostwald ripening." In this process smaller carbonate grains dissolve at the expense of secondary carbonates that form on the surface of larger grains as a means of reducing the surface free energy of sediment particles. Furthermore, this occurs without significant alteration of both carbonate composition and mineralogy (see similar results in Bischoff et al., 1987; Reid and Macintyre, 1998; Hover et al., 2001).

The occurrence of this type of carbonate dissolution/reprecipitation in sediments with moderate to high seagrass densities (see LAI values in Table 1) is consistent with previous studies which have suggested that seagrass canopies not only hinder sediment resuspension and winnowing of fine-grained particles, but may also promote the deposition of fine particles from the water column to the sediments through the dampening of water motion (Morse et al., 1987; Koch and Gust, 1999). As additional evidence of this, we have observed a weak $\left(r^{2}=0.23\right)$ but significant $(p<0.05)$ relationship between median grain size and $L A I$ in sediments we have studied across the greater expanse of the Great Bahamas Bank (including sites WS-3 and -13; see Hu, 2007).

\section{e. Reaction rates-further considerations}

Seagrass materials appeared to be the dominant organic carbon source for microbial respiration in these oligotrophic sediments, and fresh seagrass litter is generally considered to be "labile" (Boschker et al., 2000; Holmer et al., 2001; Jones et al., 2003). Therefore it appears that there was no major difference in the rates of aerobic versus anaerobic organic matter remineralization in these short-term incubations (Table 10). This observation is consistent with previous findings in the literature regarding remineralization rates of reactive organic matter under oxic versus anoxic redox conditions (see Burdige, 2006, for a review).

In the WS-3 and WS-13 incubations the ratio of the rates of carbonate reprecipitation and net carbonate dissolution $\left(R_{r x}\right)$ ranged from 0.9-2.1. This range appears to be very similar to values of this ratio in the literature for other shallow water carbonate platform sediments (e.g., 3.1-6.6 in Rude and Aller, 1990; 1.1-2.0 in Walter et al., 1993), despite the fact that these earlier studies estimated this ratio using distinctively different approaches than we used here. Although care needs to be taken when comparing these results, the agreement among all of these studies is encouraging. A combination of such methods may therefore be potentially useful in future studies examining carbonate dissolution/ reprecipitation processes in recent marine sediments.

The carbonate dissolution rates reported here are rates for surface sediments on the Bahamas Bank, and based on these results alone we have no knowledge of how the rates vary with sediment depth. However based on modeling results (Burdige et al., 2008) we have observed that carbonate dissolution occurs broadly between 1 and $9 \mathrm{~cm}$ in these sediments. Using this depth distribution, we can convert our model-derived depth integrated rates of carbonate dissolution (units of $\mathrm{mmol} \mathrm{m}^{-2} \mathrm{~d}^{-1}$ ) to volumetric 


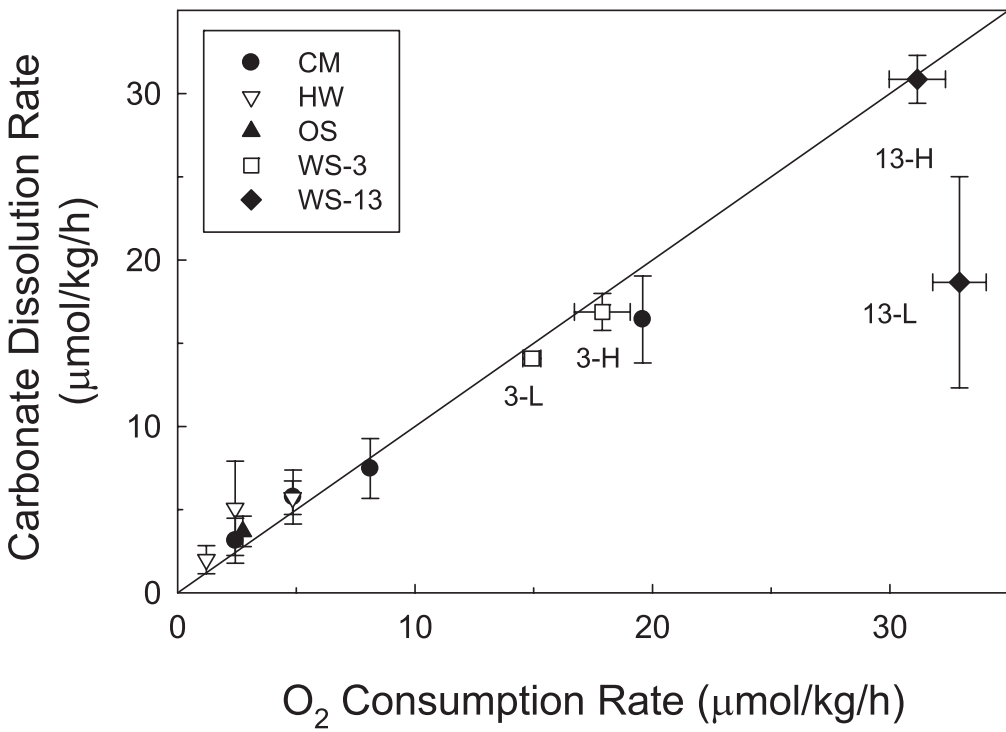

Figure 18. Carbonate dissolution rate vs. oxygen consumption rate. The carbonate dissolution rates are average values based on two end-members for the Ca concentration of the dissolving carbonate phase (see Section 4f for details). The solid line represents the 1:1 line between carbonate dissolution and oxygen consumption rates predicted if: 1. carbonate dissolution is fast relative to organic matter oxidation; and 2. the stoichiometry of rxn. (3) is correct. In all incubations except 3- $\mathrm{L}, 3-\mathrm{H}$, and $13-\mathrm{H}, \mathrm{O}_{2}$ consumption rates were assumed to be equal to the $\mathrm{O}_{2}$ delivery rates from the gas diffusion tube (see Table 3). In these three incubations $\mathrm{O}_{2}$ consumption was estimated as discussed in the text. Uncertainties are standard errors.

rates (e.g., $\mu \mathrm{M} \mathrm{d}^{-1}$ ) at discrete depths, which can then be compared with the similar volumetric rates determined in this study. In this approach we use a trapezoidal approximation of the rate profile described above, in which the carbonate dissolution rate increases linearly from 0 to a constant value between $0 \mathrm{~cm}$ and $3 \mathrm{~cm}$, remains constant at this value between $3 \mathrm{~cm}$ and $7 \mathrm{~cm}$, and then linearly decrease back to 0 between $7 \mathrm{~cm}$ and $9 \mathrm{~cm}$.

Our pore water modeling results predict depth integrated rates of carbonate dissolution in Bahamas Bank sediments that range from $\sim 1$ to $80 \mathrm{mmol} \mathrm{m}^{-2} \mathrm{~d}^{-1}$ (Hu, 2007; Burdige et al., 2008). When these integrated rates are applied to the rate profile discussed above they result in average rates in the upper $2 \mathrm{~cm}$ of sediment that range from $\sim 3$ to $23 \mu \mathrm{mol}$ $\mathrm{kg}^{-1} \mathrm{hr}^{-1}$. If we assume that the rates we have measured in this study similarly represent average rates in the upper $2 \mathrm{~cm}$ of sediment, the results in Figure 18 suggest that they range from $\sim 2$ to $\sim 30 \mu \mathrm{mol} \mathrm{kg}{ }^{-1} \mathrm{hr}^{-1}$. This comparison therefore suggests that the rates of carbonate dissolution observed in our incubations are quite close to in situ sediment carbonate dissolution rates, allowing us to use our results to examine the controls on carbonate dissolution in these sediments. 


\section{f. Role of $\mathrm{O}_{2}$ input on carbonate dissolution}

One goal of this study was to use these results to examine the stoichiometric relationship between rates of $\mathrm{O}_{2}$ consumption and net carbonate dissolution. To begin this analysis, we first assumed that all $\mathrm{O}_{2}$ consumption rates were equal to the $\mathrm{O}_{2}$ delivery rates from the gas diffusion tubes (Table 3 ). Next, $\mathrm{Ca}^{2+}$ production rates (rather than alkalinity or DIC production rates) were used to calculate net carbonate dissolution rates, given the fact that $\mathrm{Ca}^{2+}$ production in these sediments occurs unambiguously from carbonate dissolution. However in the absence of information on the exact stoichiometry of carbonate dissolution/ reprecipitation in many of these incubations, to convert these calcium production rates to carbonate dissolution rates, two end member approaches were used, based on assumptions regarding the $\mathrm{Ca}$ content of the $\mathrm{HMC}$ undergoing dissolution. In one case we assumed that this Ca content could be obtained from plots of pore water $\mathrm{d} \Delta\left[\mathrm{Ca}^{2+}\right] / \mathrm{d} \Delta\left[\mathrm{Alk}_{\mathrm{C}}\right]$ (Table 8 , see Section 4b), while in the second case we assumed that the HMC undergoing dissolution has a Ca content based on XRD results (Table 2). The uncertainty in carbonate dissolution rates shown in Figure 18 is based on the range of rates obtained from using these two approaches.

Values of the carbonate dissolution rate for each incubation are plotted versus $\mathrm{O}_{2}$ consumption rate in Figure 18. In all incubations except for the 3-L, 3-H, and 13-H incubations, this approach initially demonstrated that there was a 1:1 relationship between $\mathrm{O}_{2}$ consumption and carbonate dissolution. However in these three incubations, $\mathrm{O}_{2}$ consumption rates based on the $\mathrm{O}_{2}$ delivery rates from the diffusion tubes $(\sim 150-249$ $\left.\mu \mathrm{mol} \mathrm{kg}{ }^{-1} \mathrm{hr}^{-1}\right)$ appeared to be much greater than the carbonate dissolution rates $(\sim 15-31$ $\mu \mathrm{mol} \mathrm{kg}{ }^{-1} \mathrm{hr}^{-1}$ ); note that these results are not plotted in Figure 18, although see Hu, 2007, for details). Taken at face value, this observation might be seen as evidence of an uncoupling of aerobic respiration (rxn. 1) and carbonate dissolution (rxn. 2), implying that in these incubations aerobic respiration was sufficiently fast that carbonate dissolution became the rate-limiting step.

However, if this were the case, we would also expect to see an uncoupling of alkalinity and DIC production in these incubations, with DIC production greatly exceeding that of alkalinity. In contrast though the results in Figure 9 show that such an uncoupling was not observed in the 3-L, 3-H, and 13-H incubations, and alkalinity and DIC production rates were equal to one another in each of these incubations (also see Table 5). The reasons for this discrepancy in apparent $\mathrm{O}_{2}$ input rates and measured rates of alkalinity or DIC production in these three incubations is not well understood, although difficulties with the C-flex tubing, that was used solely in these incubations, seems a possibility.

First, the soft C-flex tubing may have been pinched by the sediments inside the incubation vial, or by the silicone septa they were passed through at the top of each vial, as opposed to the relatively more rigid Teflon tubing. Therefore $\mathrm{O}_{2}$ delivery into these tubes may have been less than the delivery rates based on the calibration curve (Fig. 4) and gas pressure readings on the regulators (see discussions in $\mathrm{Hu}, 2007$, for details). In addition, visual inspection revealed some amount of biofouling of the exterior walls of the C-flex 
tubing after these incubations, and this biofouling may also have decreased the diffusivity of $\mathrm{O}_{2}$ through this tubing inside the incubation vials. Nevertheless, the agreement between alkalinity and DIC production rates in these three incubations suggests that it is not unreasonable to assume here that the $\mathrm{O}_{2}$ consumption rates in these incubations can be estimated as being one half of the DIC (or alkalinity) production rate, as indicated in Eq. (3).

With this approach we see that the 1:1 relationship between carbonate dissolution and $\mathrm{O}_{2}$ consumption extends over the entire range of rates observed in these incubations. These results therefore indicate that metabolic $\mathrm{CO}_{2}$ production is the rate-limiting step in carbonate dissolution in these shallow-water carbonate platform sediments, consistent with other results (largely from deep-sea sediments) where it has also been observed that carbonate dissolution rates are faster than organic carbon oxidation rates at much lower overall rates of both processes (Martin et al., 2000; Martin and Sayles, 2003).

Our results also have important implications in terms of understanding carbonate dissolution in seagrass meadow sediments. In Bahamian sediments the roots and rhizomes of seagrasses penetrate up to $\sim 20 \mathrm{~cm}$ into the sediments (Hu, 2007; Burdige et al., 2008), and their sub-surface $\mathrm{O}_{2}$ input allows for much deeper oxygen penetration into these sediments than is typically observed in other coastal and shallow water sediments (e.g., Cai and Sayles, 1996; Meile and Van Cappellen, 2003). Seagrass input of $\mathrm{O}_{2}$ into carbonate seagrass sediments therefore leads to a situation in which $\mathrm{CO}_{2}$ production by aerobic respiration occurs relatively "deep" in the sediments (Burdige et al., 2008) and increases its reaction time with the carbonate sediments. This may then minimize the importance of bottom water-pore water exchange in the neutralization of this acid (e.g., Jahnke and Jahnke, 2004). When combined with the results in Figure 18, these two factors will strongly enhance metabolic dissolution efficiency (MDE) in these shallow water carbonate sediments (note that MDE is defined as the ratio of the dissolving carbonate flux and the metabolic acid production flux across the sediments-water interface; again see, e.g., Jahnke and Jahnke, 2004). However, further study of mass transport mechanisms near the sediment-water interface of these carbonate sediments will be necessary to quantitatively examine such problems.

\section{Conclusions}

In closed-system incubations sediment carbonate dissolution and $\mathrm{O}_{2}$ consumption showed a robust 1:1 linear relationship over a wide range of reaction rates. This observation further supports observations in the literature that organic carbon oxidation $\left(\mathrm{CO}_{2}\right.$ production) is the rate limiting step in metabolic carbonate dissolution. Equally important, these results further support our previous suggestions (Burdige and Zimmerman, 2002; Burdige et al., 2008) that sediment $\mathrm{O}_{2}$ input ultimately controls the occurrence of carbonate dissolution in shallow water carbonate platform sediments.

We have confirmed suggestions in the literature that high-Mg calcite with a solubility similar to or greater than that of aragonite undergoes preferential dissolution in carbonate sediments on the Bahamas Bank as a result of sedimentary microbial respiration. However 
dissolution is also accompanied by reprecipitation, and the carbonate dissolution/ reprecipitation model proposed in $\mathrm{Hu}$ and Burdige (2007) was successfully applied to the results from these incubations to explain the apparent enrichment of ${ }^{13} \mathrm{C}$ in the pore water DIC pool of these incubations. These results demonstrate that the simple 1:1 production of DIC by organic matter oxidation and carbonate dissolution cannot always be used directly to differentiate carbon sources to the pore water DIC pool of such carbonate sediments.

Carbonate reprecipitation occurred over the relatively short time scales of these experiments, suggesting that studies of pore waters can be used in addition to other geochemical techniques (such as XRD) to study carbonate diagenesis in recently deposited sediments. The calculated ratio of carbonate reprecipitation to net dissolution in our incubations $\left(R_{r x} \approx 0.9\right.$-2.1) agreed well with literature values for other shallow water carbonate sediments determined using a number of different techniques ( $\mathrm{Hu}$ and Burdige, 2007; Walter et al., 1993; Rude and Aller, 1990).

Combining pore water property-property plots with our closed system stable isotope dissolution/reprecipitation model, we have observed that the reprecipitated carbonate phase had a Mg content that is similar to or slightly lower than that of the dissolving high-Mg calcite. Dissolution/reprecipitation therefore appeared to occur by "Ostwald ripening," as has been reported in other studies of shallow water carbonate sediments.

Finally, all of these observations further reinforce conclusions reached in our earlier work (Hu and Burdige, 2007) that carbonate dissolution/reprecipitation may be important not only in shallow water carbonate platform sediments, but also in other siliciclastic coastal sediments (Eldridge and Morse, 2000; McNichol et al., 1991).

Acknowledgments. This study was supported by the NSF Chemical Oceanography Program. We thank the staff at the Caribbean Marine Research Center on LSI and the captain and crew of the R/V Walton Smith for their valuable help during our research trips. We also thank Dick Zimmerman, Fritz Neuweiler, Laura Bodensteiner, Scott Kline, and Kim Krecek for their help with sample collection and processing, and we thank Bob Dias and Joy Davis for their help with stable isotope analyses. Dick Zimmerman, Bob Dias, and Des Cook provided valuable comments to an earlier version of this work as a part of X. Hu's dissertation. Bill Martin, Don Rice and an anonymous reviewer provided critical evaluations on this manuscript that helped to significantly improve its quality.

\section{REFERENCES}

Andrews, J. E. 1991. Geochemical indicators of depositional and early diagenetic facies in Holocene carbonate muds, and their preservation potential during stabilisation. Chem. Geol., 93, 267-289.

Archer, D., S. Emerson and C. Reimers. 1989. Dissolution of calcite in deep-sea sediments: pH and $\mathrm{O}_{2}$ microelectrode results. Geochim. Cosmochim. Acta, 53, 2831-2845.

Archer, D., H. Kheshgi and E. Maier-Reimer. 1998. Dynamics of fossil fuel $\mathrm{CO}_{2}$ neutralization by marine $\mathrm{CaCO}_{3}$. Global Biogeochem. Cycles, 12, 259-276.

Bathurst, R. G. C. 1971. Carbonate Sediments and Their Diagenesis, Elsevier, 620 pp.

Berner, R. A. 1966. Chemical diagenesis of some modern carbonate sediments. Am. J. Sci., 264, $1-36$.

Berner, R. A., M. R. Scott and C. Thomlinson. 1970. Carbonate alkalinity in the pore waters of anoxic marine sediments. Limnol. Oceanogr., 15, 544-549. 
Bevington, P. R. and D. K. Robinson. 1969. Data Reduction and Error Analysis for the Physical Sciences, McGraw-Hill, 328 pp.

Bischoff, W. D., M. A. Bertram, F. T. Mackenzie and F. C. Bishop. 1993. Diagenetic stabilization pathways of magnesian calcites. Carbonates Evaporites, 8, 82-89.

Bischoff, W. D., F. T. Mackenzie and F. C. Bishop. 1987. Stabilities of synthetic magnesian calcites in aqueous solution: Comparison with biogenic materials. Geochim. Cosmochim. Acta, 51, 1413-1423.

Bodensteiner, L. B. 2006. The Impact of Light Availability on Benthic Oxygen Release by the Seagrasses-Thalassia testudinum (Banks ex König) and Zostera marina. MS Thesis, California State University.

Boschker, H. T. S., A. Wielemaker, B. E. M. Schaub and M. Holmer. 2000. Limited coupling of macrophyte production and bacterial carbon cycling in the sediments of Zostera spp. meadows. Mar. Ecol. Prog. Ser., 203, 181-189.

Boudreau, B. P. and D. E. Canfield. 1993. A comparison of closed- and open-system models for porewater $\mathrm{pH}$ and calcite-saturation state. Geochim. Cosmochim. Acta, 57, 317-334.

Broecker, W. S. and T. Takahashi. 1966. Calcium carbonate precipitation on the Bahama Banks. J. Geophys. Res., 71, 1575-1602.

Burdige, D. J. 2006. Geochemistry of Marine Sediments, Princeton University Press, 609 pp.

Burdige, D. J. and R. C. Zimmerman. 2002. Impact of seagrass density on carbonate dissolution in Bahamian Sediments. Limnol. Oceanogr., 47, 1751-1763.

Burdige, D. J., R. C. Zimmerman and X. Hu. 2008. Rates of carbonate dissolution in permeable sediments estimated from pore water profiles: the role of seagrasses. Limnol. Oceanogr., 53, 549-565.

Cai, W.-J. and F. L. Sayles. 1996. Oxygen penetration depths and fluxes in marine sediments. Mar. Chem., 52, 123-131.

Caldeira, K. and G. H. Rau. 2000. Accelerating carbonate dissolution to sequester carbon dioxide in the ocean: Geochemical implications. Geophys. Res. Lett., 27, 225-228.

Cline, J. D. 1969. Spectrophotometric determination of hydrogen sulfide in natural waters. Limnol. Oceanogr., 14, 454-458.

Cole, D. R. and S. Chakraborty. 2001. Rates and mechanisms of isotopic exchange, in Stable Isotope Geochemistry, J. W. Valley and D. R. Cole, eds., Mineralogical Society of America, 83-223.

Dickson, A. G., J. D. Afghan and G. C. Anderson. 2003. Reference materials for oceanic $\mathrm{CO}_{2}$ analysis: a method for the certification of total alkalinity. Mar. Chem., 80, 185-197.

Dickson, A. G., C. L. Sabine and J. R. Christian. 2007. Guide to Best Practices for Ocean $\mathrm{CO}_{2}$ Measurements. PICES Special Publication 3, $191 \mathrm{pp}$.

Eldridge, P. M. and J. W. Morse. 2000. A diagenetical model for sediments-seagrass interactions. Mar. Chem., 70, 89-103.

Goldsmith, J. R., D. L. Graf and H. C. Heard. 1961. Lattice constants of the calcium-magnesium carbonates. Am. Mineral., 46, 453-457.

Grasshoff, K., K. Kremling and M. Ehrhardt. 1999. Methods of Seawater Analysis, Wiley-VCH, 600 pp.

Green, M. A. and R. C. Aller. 1998. Seasonal patterns of carbonate diagenesis in nearshore terrigenous muds: Relation to spring phytoplankton bloom and temperature. J. Mar. Res., 56, 1097-1123.

2001. Early diagenesis of calcium carbonate in Long Island Sound sediments: Benthic fluxes of $\mathrm{Ca}^{2+}$ and minor elements during seasonal periods of net dissolution. J. Mar. Res., 59, 769-794.

Grice, A. M., N. R. Loneragan and W. C. Dennison. 1996. Light intensity and the interactions between physiology, morphology and stable isotope ratios in five species of seagrass. J. Exp. Mar. Biol. Ecol., 195, 91-110.

Hemminga, M. A. and C. M. Duarte, 2000. Seagrass Ecology. Cambridge University Press, 310 pp. 
Hofmann, M., D. A. Wolf-Gladrow, T. Takahashi, S. C. Sutherland, K. D. Six and E. Maier-Reimer. 2000. Stable carbon isotope distribution of particulate organic matter in the ocean: a model study. Mar. Chem., 72, 131-150.

Holmer, M., F. O. Andersen, S. L. Nielsen and H. T. S. Boschker. 2001. The importance of mineralization based on sulfate reduction for nutrient regeneration in tropical seagrass sediments. Aquat. Bot., 71, 1-17.

Hover, V. C., L. M. Walter and D. R. Peacor. 2001. Early marine diagenesis of biogenic aragonite and Mg-calcite: new constrains from high-resolution STEM and AEM analysis of modern platform carbonate. Chem. Geol., 175, 221-248.

Hu, X. 2007. Seagrass Mediated Carbonate Dissolution and Early Diagenesis in Bahamas Bank Sediments. Ph. D. Dissertation, Old Dominion University.

$\mathrm{Hu}, \mathrm{X}$. and D. J. Burdige. 2007. Enriched stable carbon isotopes in the pore waters of carbonate sediments dominated by seagrasses: evidence for coupled carbonate dissolution and reprecipitation. Geochim. Cosmochim. Acta, 71, 129-144.

Hulthe, G., S. Hulth and P. O. J. Hall. 1998. Effect of oxygen on degradation rate of refractory and labile organic matter in continental margin sediments. Geochim. Cosmochim. Acta, 62, 13191328.

Jahnke, R. A. and D. B. Jahnke. 2004. Calcium carbonate dissolution in deep sea sediments: Reconciling microelectrode, pore water and benthic flux chamber results. Geochim. Cosmochim. Acta, 68, 47-59.

Jones, W. B., L. A. Cifuentes and J. E. Kaldy. 2003. Stable carbon isotope evidence for coupling between sedimentary bacteria and seagrasses in a sub-tropical lagoon. Mar. Ecol. Prog. Ser., 255, $15-25$.

Kanamori, S. and H. Ikegami. 1980. Computer-processed potentiometric titration for the determination of calcium and magnesium in sea water. J. Oceanogr., 36, 177-184.

Koch, E. W. and G. Gust. 1999. Water flow in tide- and wave-dominated beds of the seagrass Thalassia testudinum. Mar. Ecol. Prog. Ser., 184, 63-72.

Ku, T. C. W., L. M. Walter, M. L. Coleman, R. E. Blake and A. M. Martini. 1999. Coupling between sulfur recycling and syndepositional carbonate dissolution: evidence from oxygen and sulfur isotope composition of pore water sulfate, South Florida Platform, U.S.A. Geochim. Cosmochim. Acta, 63, 2529-2546.

Lewis, E. and D. Wallace. 1998. Program Developed for $\mathrm{CO}_{2}$ System Calculations. ORNL/CDIAC105. Carbon Dioxide Information Analysis Center, Oak Ridge National Laboratory, U.S. Department of Energy, Oak Ridge, Tennessee.

Martin, W. R., A. P. McNichol and D. C. McCorkle. 2000. The radiocarbon age of calcite dissolving at the sea floor: Estimates from pore water data. Geochim. Cosmochim. Acta, 64, 1391-1404.

Martin, W. R. and F. L. Sayles. 2003. The recycling of biogenic material at the seafloor, in Treatise on Geochemistry, F. T. Mackenzie, ed., Elsevier, 37-65.

McNichol, A. P., E. R. M. Druffel and C. Lee. 1991. Carbon cycling in coastal sediments: 2. An Investigation of the sources of $\mathrm{SCO}_{2}$ to pore water using carbon isotopes, in Organic Substances and Sediments in Water, R. A. Baker, ed., Lewis Publishers, 249-272.

Meile, C. and P. Van Cappellen. 2003. Global estimates of enhanced solute transport in marine sediments. Limnol. Oceanogr., 48, 777-786.

Milliman, J. D. 1974. Marine Carbonates, Springer-Verlag, 375 pp.

- 1993. Production and accumulation of calcium carbonate in the ocean: budget of a nonsteady state. Global Biogeochem. Cycles, 7, 927-957.

Milliman, J. D., D. Freile, R. P. Steinen and R. J. Wilber. 1993. Great Bahama Bank aragonite muds: mostly inorganically precipitated, mostly exported. J. Sediment. Petrol., 63, 589-595.

Morse, J. W., A. J. Andersson and F. T. Mackenzie. 2006. Initial responses of carbonate-rich shelf 
sediments to rising atmospheric $\mathrm{pCO}_{2}$ and "ocean acidification": Role of high Mg-calcites. Geochim. Cosmochim. Acta, 70, 5814-5830.

Morse, J. W. and F. T. Mackenzie. 1990. Geochemistry of Sedimentary Carbonates,. Elsevier, 707 pp.

Morse, J. W. and A. Mucci. 1984. Composition of carbonate overgrowths produced on Iceland spar calcite crystals buried in Bahamian carbonate-rich sediments. Sediment. Geol., 40, 287-291.

Morse, J. W., J. J. Zullig, L. D. Bernstern, F. J. Millero, P. Milne, A. Mucci and G. R. Choppin. 1985. Chemistry of calcium carbonate-rich shallow water sediments in the Bahamas. Am. J. Sci., 285, $147-185$.

Morse, J. W., J. J. Zullig, R. L. Iverson, G. R. Choppin, A. Mucci and F. J. Millero. 1987. The influence of seagrass beds on carbonate sediments in the Bahamas. Mar. Chem., 22, 71-83.

Mucci, A. 1983. The solubility of calcite and aragonite in seawater at various salinities. Am. J. Sci., 283, 780-799.

Mucci, A. and J. W. Morse. 1983. The incorporation of $\mathrm{Mg}^{2+}$ and $\mathrm{Sr}^{2+}$ into calcite overgrowths: influences of growth rate and solution composition. Geochim. Cosmochim. Acta, 47, 217-233.

Patterson, W. P. and L. M. Walter. 1994. Syndepositional diagenesis of modern platform carbonates: Evidence from isotopic and minor element data. Geology, 22, 127-130.

Pilson, M. E. Q. 1998. An Introduction to the Chemistry of the Sea, Prentice Hall, 431 pp.

Plummer, L. N. and F. T. Mackenzie. 1974. Predicting mineral solubility from rate data: application to the dissolution of magnesian calcites. Am. J. Sci., 274, 61-83.

Rasmussen, K. A., R. I. Haddad and A. C. Neumann. 1990. Stable-isotope record of organic carbon from an evolving carbonate banktop, Bight of Abaco, Bahamas. Geology, 18, 790-794.

Reid, R. P. and I. G. Macintyre. 1998. Carbonate recrystallization in shallow marine environments: a widespread diagenetic process forming micritized grains. J. Sediment. Res., 68, 928-946.

Rubinson, M. 1969. Carbon-13 fractionation between aragonite and calcite. Geochim. Cosmochim. Acta, 33, 997-1002.

Rude, P. D. and R. C. Aller. 1991. Fluorine mobility during early diagenesis of carbonate sediment: An indicator of mineral transformation. Geochim. Cosmochim. Acta, 55, 2491-2509.

Salata, G. G., L. A. Roelke and L. A. Cifuentes. 2000. A rapid and precise method for measuring stable carbon isotope ratios of dissolved inorganic carbon. Mar. Chem., 69, 153-161.

Sanders, D. 2003. Syndepositional dissolution of calcium carbonate in neritic carbonate environments: geological recognition, processes, potential significance. J. Afr. Earth Sci., 36, 99-134.

Sayles, F. L. and W. B. Curry. 1988. $\delta^{13} \mathrm{C}, \mathrm{TCO}_{2}$, and the metabolism of organic carbon in deep-sea sediments. Geochim. Cosmochim. Acta, 52, 2963-2978.

Stoessell, R. K. 1992. Effects of sulfate reduction on $\mathrm{CaCO}_{3}$ dissolution and precipitation in mixing-zone fluids. J. Sediment. Petrol., 62, 873-880.

Tussenboek, B. I. V., J. A. Vonk, J. Stapel, P. L. A. Erftemeijer, J. J. Middelburg and J. C. Zieman. 2006. The Biology of Thalassia: Paradigms and Recent Advances in Research, in Seagrasses: Biology, Ecology and Conservation, A. W. D. Larkum, R. J. Orth and C. M. Duarte, eds., Springer, 409-439.

Walter, L. M. and E. A. Burton. 1990. Dissolution of recent platform carbonate sediments in marine pore fluids. Am. J. Sci., 290, 601-643.

Walter, L. M., T. C. W. Ku, K. Muehlenbachs, W. P. Patterson and L. Nonnell. 2007. Controls on the $\delta^{13} \mathrm{C}$ of dissolved inorganic carbon in marine pore waters: An integrated case study of isotope exchange during syndepositional recrystallization of biogenic carbonate sediments (South Florida Platform, USA). Deep-Sea Res., II, 54, 1163-1200.

Walter, L. M. and J. W. Morse. 1984. Magnesian calcite stabilities: A reevaluation. Geochim. Cosmochim. Acta, 48, 1059-1069. 